NBER WORKING PAPER SERIES

\title{
VENTURE CAPITAL INVESTMENTS AND MERGER AND ACQUISITION ACTIVITY AROUND THE WORLD
}

Gordon M. Phillips

Alexei Zhdanov

Working Paper 24082

http://www.nber.org/papers/w24082

\author{
NATIONAL BUREAU OF ECONOMIC RESEARCH \\ 1050 Massachusetts Avenue \\ Cambridge, MA 02138 \\ November 2017
}

We thank Tom Blaisdell, Laurent Fresard, Karl Lins, Merih Sevilir and seminar participants at the University of Hong Kong, HKUST, Indiana University and Michigan State University for helpful comments. The views expressed herein are those of the authors and do not necessarily reflect the views of the National Bureau of Economic Research.

NBER working papers are circulated for discussion and comment purposes. They have not been peer-reviewed or been subject to the review by the NBER Board of Directors that accompanies official NBER publications.

(C) 2017 by Gordon M. Phillips and Alexei Zhdanov. All rights reserved. Short sections of text, not to exceed two paragraphs, may be quoted without explicit permission provided that full credit, including $\odot$ notice, is given to the source. 
Venture Capital Investments and Merger and Acquisition Activity Around the World Gordon M. Phillips and Alexei Zhdanov

NBER Working Paper No. 24082

November 2017

JEL No. G3,G34,L12,O3,O31,O34

\begin{abstract}
$\underline{\text { ABSTRACT }}$
We examine the relation between venture capital (VC) investments and mergers and acquisitions (M\&A) activity around the world. We find evidence of a strong positive association between VC investments and lagged M\&A activity, consistent with the hypothesis that an active M\&A market provides viable exit opportunities for VC companies and therefore incentivizes them to engage in more deals. We also explore the effects of country-level pro-takeover legislation passed internationally (positive shocks), and US state-level antitakeover business combination laws (negative shocks), on VC activity. We find significant post-law changes in VC activity. VC activity intensifies after enactment of country-level takeover friendly legislation and decreases following passage of state antitakeover laws in the U.S.
\end{abstract}

Gordon M. Phillips

Tuck School of Business

Dartmouth College

100 Tuck Hall

Hanover, NH 03755

and NBER

gordon.m.phillips@gmail.com

Alexei Zhdanov

Penn State University

State College, PA 16802

auz15@psu.edu 


\section{Introduction}

Venture capital funding is important to many small innovative firms, allowing them to survive and prosper. In this paper, we study the interaction of the merger market with venture capital in a sample of 48 countries around the world. The impact of mergers on innovation overall is a large topic of debate. Many government agencies and academic scholars worry that the M\&A market may hinder the incentives for innovation. ${ }^{1}$ In particular, the Department of Justice and the Federal Trade Commission have challenged many mergers based on the concern that mergers destroy the incentives to innovate. In a recent paper, Gilbert and Green (2015) show that between 2004 and 2014, $33.2 \%$ of mergers were challenged due to alleged harm to innovation. Furthermore, starting in 2010, the DOJ and FTC formally and explicitly addressed innovation in their merger guidelines. ${ }^{2}$ Waller and Sag (2015) also emphasize the importance of considering post-merger incentives for future innovation, but argue that a merger can decrease incentives to innovate by removing the threat of outside disruption.

We argue that active M\&A markets promote innovation investments and make it easier for venture capitalists to monetize their investment by selling their portfolio companies to potential acquirers. We examine VC investments following M\&A activity and also VC investments subsequent to passage of pro-takeover and anti-takeover legislation. While mergers of firms that are horizontally competing may indeed reduce innovation, general policies where a large firm is prevented from buying a smaller firm may have deleterious effects on the ex ante incentives to conduct R\&D by the smaller firm, as has been emphasized by Phillips and Zhdanov (2013). This argument is further supported by Bena and Li (2014), who show that large companies with low R\&D expenditures are more likely to be acquirers, and argue that synergies obtained from combining innovation capabilities are important drivers of acquisitions.

We begin our analysis by examining how VC investments over the period of 1985 to 2014 respond to changes in $\mathrm{M} \& \mathrm{~A}$ activity, while controlling for other potential determinants of $\mathrm{VC}$

\footnotetext{
${ }^{1}$ See Schulz (2007) for a literature review on mergers and innovation.

${ }^{2}$ These challenges existed in previous periods as well. Gilbert (2007) gives summary statistics that show that in 2000-2003, 38\% of the mergers challenged in the U.S. were challenged due to alleged harm to innovation.
} 
activity. Our results confirm that there exists a strong positive association between activity in M\&A markets and subsequent investments by VC firms. We then look deeper into the dynamics of $\mathrm{VC}$ and M\&A activities and perform additional tests to understand the relation between VC and M\&A activity. To begin, we follow Harford (2005) and construct merger wave indicators for both $\mathrm{VC}$ and M\&A markets. For this purpose, we take the total number of deals in a country-industry and simulate 1000 deal distributions by randomly assigning deals over our time period of 1985-2014. We then calculate the highest two-year transaction concentration from each of the 1000 draws. If the actual number of transactions in a two year period exceeds the 95th percentile from these simulated distributions, that period is identified as a wave. We then examine the joint timing of $\mathrm{VC}$ and $\mathrm{M} \& \mathrm{~A}$ waves and find that an M\&A wave is a strong predictor of a future $\mathrm{VC}$ wave in the same country-industry.

While there is a strong correlation between VC activity and lagged M\&A activity, it is important to recognize that both $\mathrm{VC}$ investments and M\&A activity are likely to be driven by common demand shocks and technological changes. We partially address the potential endogeneity concern that both types of activity can be simultaneously driven by the same exogenous economic shocks in three different ways. First, we instrument cross-border M\&A activity with local currency depreciations. Following Erel, Liao, and Weisbach (2012) we argue that a weaker currency makes local companies potentially cheaper acquisition targets for foreign investors and hence is likely to have a positive effect on cross-border M\&A activity. On the other hand, domestic VC investments may not be affected by the strength of local currency if a currency depreciation is a sign of weakened economic activity. We therefore use local currency depreciation as an instrument for cross-border M\&A activity. Our results show that the cross-border M\&A intensity instrumented this way is a strong predictor of future domestic VC deals consistent with an active M\&A market, translating into more potential exit opportunities for $\mathrm{VC}$ investors.

Second, we take advantage of changes to M\&A legislation both at a country level as well as at a state level in the United States. Country-level pro-takeover legislation was passed in various countries in our sample in different years with the intention to make M\&A markets 
more attractive. These law changes serve as a natural ground to study the effect of positive shocks to M\&A markets on subsequent activity by VC firms. On the contrary, US based state-level antitakeover business combination laws provide an opportunity to study the effect of negative shocks to the feasibility of takeovers.

We follow Lel and Miller (2015) in the examination of the effects of pro-takeover international legislation on firm policies. They focus on managerial discipline and find that following the enactment of country pro-takeover laws, poorly performing firms experience more frequent takeovers and have an increased propensity to replace underperforming CEOs. ${ }^{3}$ They also verify that country takeover-friendly laws indeed spur more M\&A activity in the country. Our focus is the effect of pro-takeover laws on VC markets. Using a difference-in-difference approach at the country-industry level we investigate the impact of takeover-friendly legislation on subsequent VC investments.

This analysis compares VC investments in countries that are subject to change in takeover legislation with VC activity in countries that have no such change. In our tests, we control for time-invariant country and industry characteristics by including country and industry fixed effects. Time-varying economic conditions that have a potential effect on VC investments are controlled for by year fixed effects. Our evidence shows increases in VC activity after pro-takeover laws. VC activity grows by about 40-50\% more from pre-law periods to post-law periods in countries that enact pro-takeover laws versus those that do not. This evidence provides support for our hypothesis that M\&A and VC markets are connected and improvements in M\&A legislation spill over to $\mathrm{VC}$ markets by creating more viable exit opportunities for VC firms.

Third, we shift our focus to the US and examine the effect of state-level anti-takeover business combination laws on $\mathrm{VC}$ investments in states that enact such laws. These laws impose a moratorium on certain kinds of transactions (e.g., asset sales, mergers) between a

\footnotetext{
${ }^{3}$ See also Bhattacharya and Daouk (2002) on the effect of insider trading laws and their enforcement around the world, Iliev et al (2015) on the effect of international laws (including M\&A laws) on shareholder voting and corporate governance, and Lins, Servaes, and Tufano (2010) for an international study of the use of lines of credit versus cash.
} 
large shareholder and the firm for a period usually ranging between three and five years after the shareholder's stake passes a pre-specified (minority) threshold. These laws are in place in 28 U.S. States in our sample and were passed between 1985 and 1991. We argue that there are multiple channels through which the business combination laws might affect VC investments. First, while intended to protect shareholders from hostile takeovers, business combination laws can potentially increase the cost to the acquiring firm and have a negative effect on M\&A markets in general. Second, we argue that takeovers (including hostile ones) can result in more firm creation and hence $\mathrm{VC}$ funding as entrepreneurial employees leave to found new start-up companies. In a context of corporate bankruptcy, Babina (2016) shows that employer financial distress accelerates the exit of employees to create start-ups. Atanassov (2013) shows that antitakeover laws have a negative effect on firm's innovation as measured by patent grants and citations.

To study the relation between business combination laws and VC activity, we again employ a difference-in-difference methodology and examine the difference in VC deal intensity in the years following an enactment of an antitakeover law in states that pass a law (treatment states) versus those that did not (control states). Consistent with our hypothesis, our results show that both the level and growth of VC intensity declines in treatment states relative to control states after passage of business combination laws.

Overall, our results emphasize the importance of M\&A markets for the investment activities of VC firms. As many start-ups rely on $\mathrm{VC}$ funding ${ }^{4}$ and venture capitalists rely more on exits through acquisitions versus IPOs, our results suggest that active M\&A markets have important ex ante incentive effects for generating entrepreneurship and growth. We focus on the ex ante incentive effects but as a matter of practice actual exits via mergers and trade sales represent almost $6 \mathrm{x}$ the incidence of IPOs. ${ }^{5}$ Our results are consistent with an active M\&A market providing incentives for venture capitalists to engage in more deals.

\footnotetext{
${ }^{4}$ See also Hellman and Puri (2002) who show that involvement of VC firms enhances the professionalization of start-ups.

${ }^{5}$ Using Prequin data which has data on exits, we find that mergers and trade sales represent $76.61 \%$ of exits versus $13.74 \%$ via IPOs. The balance of actual exits were through sales to other GPs or management, private placements and recapitalizations.
} 
Our paper examines the joint dynamics of M\&A and VC activities and is therefore related to both the merger literatures and the VC literatures. To the best of our knowledge, this is the first paper that studies the joint dynamics of both M\&A and VC transactions. We go beyond just US-based evidence to provide international evidence on time varying $\mathrm{VC}$ and M\&A markets. Gompers and Lerner (2004) provide extensive evidence of time-variability of VC investments as well as fund flows to VC firms. Gompers, Kovner, Lerner and Scharfstein (2008) examine the relation between changes in public market signals and VC activity and document wave-like patterns of VC activity in the US. These papers focus solely on the US and do not examine the link between VC activity and acquisition activity. Robinson and Sensoy (2016) examine the cyclicality of cash flows and performance in private equity and VC markets. Lerner, Schoar, Sokolinksi, and Wilson (2016) study the activity of angel investors in 21 countries. Dittmar and Dittmar (2008) study the joint relation between share repurchases, equity issuance, and mergers. Lyandres, Zhdanov, and Hsieh (2013) present a theory and evidence of the joint dynamics of IPO and M\&A activities. Celikyurt, Sevilir, and Shivdasani (2010) and Hovakimian and Hutton (2010) examine various motives for potential relation between M\&A and IPO waves. Our analysis extends the literature by moving beyond US data to examine a sample of 48 different countries around the world. We also study the link between M\&A and VC activity. Furthermore, we take advantage of the natural shocks to M\&A markets, both positive (country takeover laws) and negative (US state business combination laws) and study what happens to subsequent VC activity.

The remainder of the paper is organized as follows. Section 2 describes our data sources and the main variables that we use in our analysis. In section 3 we develop our main hypotheses. Section 4 examines the link between M\&A and VC markets in a regressions framework, and also by using an instrumental variable approach while instrumenting cross-border M\&A activity with the strength of the currency in the target country. In that section we also analyze the joint dynamics of $\mathrm{VC}$ and $\mathrm{M} \& \mathrm{~A}$ waves. In section 5 we study the effects of country takeover law initiations on subsequent investments by VC firms. Section 6 examines the response of VC investments to state antitakeover laws in the US. Section 7 concludes. 


\section{Data and Variables}

We combine data from four major sources. Data on venture capital transactions are obtained from Thomson Reuters Venture Expert. VC data is very limited before the mid 1980s, and we therefore start our sample in 1985. To ensure that we have a reasonable number of firms in a country for our cross-sectional country-level tests, we drop countries with less than 100 total VC deals recorded in Venture Expert. We follow Gompers et al (2008) and define VC deals at the VC firm - portfolio company level. This approach results in multiple observations if several VC firms invest in a particular company (in our sample there are on average around two VC firms per investment). We restrict our sample to Venture Capital Deals, defined by Venture Expert as "Venture capital investments that include startup/seed, early, expansion, and later stage deals, or any non venture stage investments made by traditional venture focused firms." M\&A transaction data come from the Security Data Corporation's (SDC) Mergers and Corporate Transaction database and includes all deals (domestic and cross-border) announced and completed between 1985 and 2014. Similarly to Erel, Liao, and Weisbach (2012) we exclude LBOs, spinoffs, re-capitalizations, self-tender offers, exchange offers, repurchases, partial equity stakes, acquisitions of remaining interest, privatizations, as well as deals in which the target or the acquirer is a government agency. In our main tests we consider investments in a single portfolio company on the same date as a single VC deal, even if there are multiple $\mathrm{VC}$ firms involved. Our results hold if we treat these investments by multiple VC firms as multiple deals (see Table A.3 in the appendix). Because we use IPO activity as a control variable in some of our tests, we obtain IPO data also from Security Data Corporation. Table 1 presents the distribution of M\&A and VC deals by country.

Insert Table 1 Here

Following Gompers et al. (2008), we also consider unique VC deals by excluding any follow-up financing rounds so every venture capital firm - portfolio company pair appears only 
once in the sample of unique deals. Note that based on this definition the number of unique deals can be both higher and lower than the number of deals (depending on how many VC firms participate in a single deal and also on the number of financing rounds.) As follows from Table 1, while the majority of VC deals involves financing of US-based companies (about $60 \%$ in our sample of unique deals), there is still substantial VC activity outside of the US, in particular in Canada, developed European countries (UK, France, Germany) as well as some emerging Asian markets (China, South Korea). Our resulting dataset contains 201,010 venture capital deals, 226,896 unique VC deals (one deal per venture capital firm - portfolio company pair) and 397,871 takeover transactions. On the M\&A side the US is again not surprisingly the country with the largest number of deals in our dataset (in excess of 187,000 deals or $47.1 \%$ of all deals), followed by the UK (12.4\%), Canada (5.7\%), Germany (4.7\%) and France (4.6\%).

We collect accounting data for international (US) companies from Worldscope (Compustat) and return data from Datastream (CRSP). While our main variables of interest are related to the dynamics of $\mathrm{VC}$ investments, we need these accounting data to construct various control variables that are known to potentially affect M\&A and VC activities. We also use the number of public firms in the Worldscope database as a scaling factor in some measures of M\&A and VC intensities that we use. Our joint public firm dataset spans 66,213 firms across 48 countries. Of these firms, 24,466 firms are in the US. (Followed by 5,100 firms in Japan and 4,333 firms in the UK). While COMPUSTAT offers comprehensive coverage of public firms throughout our sample, consistent Worldscope coverage for developed countries starts in 1990s and does not start until the early 2000s for many emerging countries (e.g. China.)

Figure 1 plots the aggregate numbers of $\mathrm{VC}$ and M\&A deals in the US and in the rest of the world, by year (Panel A). Panel B of figure 1 further breaks down the international VC and M\&A activity into those in developed and emerging countries, as classified by MSCI. In both panels, in addition to total $\mathrm{VC}$ deals we also present unique $\mathrm{VC}$ deals, constructed as 
described above.

Insert Figure 1 Here

As follows from Figure 1, VC activity (as measured by the numbers of both total and unique deals) exhibits similar time patterns in the US and internationally, with a clear peak around the 2000 dotcom bubble and subsequent flattening out with an additional peak in the pre-crisis period and a decline corresponding to the 2008 financial crisis.

We use SIC2 codes to group firms into industries, resulting in 77 industries. Given the structure of our data, this industry breakdown provides the optimal degree of coarseness of the distribution of VC deals by country-industries. There is still, however, substantial variation in the number of deals within an industry across different countries. To further reduce noise in our estimation, we exclude country-industry-years with less than three VC deals in our dataset. As expected, some industries have higher populations of entrepreneurial firms and attract more attention from VC firms than others, so the resulting distribution of deals by industries is skewed. The industries with the highest numbers of deals in our sample are "Business Services," "Electronic and Other Electric Equipment," and "Chemical \& Allied Products" (including pharmaceutical products). The industries with least VC deals are public administration and utilities industries as well as "Tobacco Products" and "Museums, Botanical, Zoological Gardens." There is also variation in VC activity within industries over time. For example, the number of unique deals in the US "Business Services" industry (sic code 73) grows from 1,123 in 1996 to 3,599 in 2000 (the year when the dot-com bubble burst) and then goes down to 1,477 in 2003. We formally analyze the presence of waves in VC and M\&A markets and their joint dynamics in section 4.2 below.

Transaction values are very often missing in Venture Expert and we therefore follow Gompers (2008) and use the number of deals to measure M\&A and VC intensities. In particular, we use two alternative measures of VC and M\&A activities. Our first measure captures the level 
of those activities and is defined as the total number of deals in a country (or country-industry) scaled by the total number of public firms in that country (country-industry):

$$
D E A L S \text { level }_{i . j, t}=N\left(\text { Deals }_{i, j, t}\right) / N\left(\text { Public Firms }_{i, j, t}\right) .
$$

In equation (1) Deals $\mathrm{s}_{i, j, t}$ is the number of VC (M\&A) deals in country $i$, industry $j$ in year $t$

while Public Firms $i_{i, j, t}$ is the number of public firms available in Worldscope (for international data) or CRSP (for US data) in the same country-industry-year. In addition to the measures expressed in levels, we also use the growth in numbers of $\mathrm{VC}$ and $\mathrm{M} \& \mathrm{~A}$ deals defined as the percentage change in the number of deals from one year to the next in the same countryindustry:

$$
D E A L S \_ \text {change } e_{i, j, t}=\frac{N\left(\text { Deals }_{i, j, t}\right)}{N\left(\text { Deals }_{i, j, t-1}\right)}-1 .
$$

In our empirical analysis below we apply these measures to total VC deals, unique VC deals, as well as M\&A transactions.

\section{Interaction of M\&A and VC Activity}

In this section we describe the main hypotheses we will test in this paper. Our main objective in this paper is to shed light on the interaction between $\mathrm{VC}$ and M\&A markets. We argue that exit through an acquisition provides a viable means for $\mathrm{VC}$ firms to monetize their investments in portfolio companies. We focus on the ex ante incentive effects but actual exits (not including firms that failed or which no exit data can be found) via mergers and trade sales represent almost $6 \mathrm{x}$ the incidence of IPOs. Using Prequin data which has data on exits, we find that mergers and trade sales represent $76.61 \%$ of exits versus $13.74 \%$ via IPOs. The balance of actual exits were through sales to other GPs or management, private placements and recapitalizations. 
We argue that venture capitalists are more likely to initiate new investments when the M\&A market heats up and there are more M\&A deals. Active M\&A markets transpire into more viable exit opportunities. The challenge is that we recognize that for demand and technological reasons, these two markets may be very related and thus VC investments may respond to these demand and technological changes. We are attempting to identify the channel where VC investors look at the potential for exit from the M\&A market and in particular from related strategic buyers. The first hypothesis we examine does not attempt to discern why these markets may be related. The second and third hypotheses and associated tests attempt to isolate the M\&A exit channel as a potential motivation for $\mathrm{VC}$ investors.

Hypothesis 1: There is a positive association between $V C$ investments and lagged M\& $A$ activity.

While it is useful to establish a relation between M\&A and VC markets, a potential concern is that these two types of activity are driven by common economic shocks - both demand and technological. Thus, rather than VC deals responding to improvements in M\&A markets, both types of activity might be responding to some changes in the underlying economic environment. We address this issue by using lags in our regression specifications and including time and country fixed effects in our regressions. We also perform three additional types of tests. First, we identify waves in both M\&A and VC markets as periods of abnormally high activity in those markets and study the relation between those two types of waves. The details on this procedure are presented in section 4.2 below. Second, we use an instrumental variable approach and instrument cross-border M\&A activity with local currency depreciation. In the second stage, we examine the relation between domestic VC activity and instrumented cross-border M\&A activity.

Third, to further isolate the M\&A exit channel, we also exploit exogenous shocks to M\&A markets. We take advantage of both positive and negative shocks to takeover legislation. On the positive side, we focus on the staggered enactment of country-level takeover laws. Such laws are intended to simplify the takeover process and make country legislation more 
takeover friendly and therefore induce more M\&A activity in the future. As Lel and Miller (2015) argue, legal changes associated with country M\&A laws are significant, because they are passed to foster takeover activity by reducing barriers to M\&A transactions and the legal framework applicable to such transactions. However, there is no obvious direct causation between enactment of takeover laws and VC activity. Still, we expect that such laws would have an indirect positive effect on VC investments, as venture capitalists rationally expect the takeover market to heat up following the passage of takeover laws and provide them with more exit opportunities. This conjecture is summarized in Hypothesis 2.

Hypothesis 2: VC activity intensifies following the passage of country takeover laws.

On the negative side, we exploit shocks to takeover legislation in the form of state antitakeover business combination laws in the US. We believe that business combination laws are exogenous to VC activity because they are most likely outside of control of VC firms and also because they are often lobbied for by specific companies. These laws impose a three to five year moratorium on certain types of transactions, such as mergers, divestitures, consolidations, share exchanges, leases, transfers, liquidations, dissolutions, and asset sales between the firm and a large shareholder whose stake in the firm passes a pre-specified threshold. While their focus is on hostile takeovers, state business combination laws can negatively affect the M\&A markets in general and therefore make potential exit of VC investors through an acquisition less viable. Furthermore, takeovers (both friendly and hostile) might create incentives for entrepreneurial employees to leave and start their own firms that require funding by VC companies. An antitakeover law would negatively affect such entrepreneurial activity. We therefore expect VC activity in a state that passes an antitakeover law to cool down following enactment of that law.

Hypothesis 3: There is a reduction in VC activity following enactment of state antitakeover laws.

The key comparison here is to compare states which pass an antitakeover law in a particular year with states which do not pass an antitakeover law in the same year. The staggered 
implementation of the antitakeover laws was used by Bertrand and Mullainathan (2003) and recently by Giroud and Mueller (2010).

\section{4. $\mathrm{VC}$ investments and M\&A activity}

\subsection{Regressions of $V C$ activity}

We first look at the joint dynamics of M\&A and VC markets by computing contemporaneous and lagged correlations between measures of M\&A and VC activities. Because IPOs represent an alternative exit channel for VC investors, we also include measures of IPO activity in our analysis. We use the measures of M\&A, VC, and IPO intensities expressed in both levels and changes, as specified by equations (1) and (2). Following Gompers et al (2008), we construct a measure of unique $\mathrm{VC}$ deals (by excluding any follow up financing rounds from the same VC firm in the same portfolio company). Table 2 reports correlations at the country-industry level. Panel A presents results for percentage changes in the numbers of deals, while panel B reports correlations between VC, M\&A, and IPO transactions scaled by the number of public firms in the country-industry.

Insert Table 2 Here

The results in Table 2 show that there is a strong positive and statistically significant correlation between $\mathrm{VC}$ activity and both contemporaneous and lagged M\&A activity. Correlations are positive and significant for measures expressed in levels as well as in changes. For example, contemporaneous (lagged) correlations between percentage growth in $\mathrm{VC}$ and $\mathrm{M} \& \mathrm{~A}$ deals are 0.094 and 0.051 , while similar correlations between the numbers of deals are 0.540 and 0.345 , respectively. Negative correlations between contemporaneous and lagged changes in the number of deals (-0.195 for VC deals and -0.138 for M\&A transactions) are mechanically driven by scaling our growth measures by the lagged number of deals. Thus, preliminary correlationbased evidence strongly suggests that M\&A and VC markets are not independent and there 
is a strong association between the two markets. Note also, that correlations between current $\mathrm{VC}$ and lagged M\&A activities are higher than those between current M\&A and lagged VC activities, suggesting that in general M\&A markets tend to lead. Furthermore, coefficients on lagged M\&A measures are higher than those on lagged IPO measures (in addition, the correlation between VC growth and lagged IPO growth is insignificant).

To further investigate the joint dynamics of VC and M\&A investments, we turn our analysis to multivariate tests of the determinants of VC activity. In particular, we adopt the following empirical specification:

$$
V C_{i, j, t}=\alpha+\beta M A_{i, j, t-1}+\delta X_{i, j, t-1}+v_{t}+\varepsilon_{i, j, t}
$$

where $V C_{i, j, t}$ is a measure of $\mathrm{VC}$ activity in country $i$ and industry $j$ in year $t, M A_{i, j, t-1}$ is a measure of M\&A activity in country $i$ and industry $j$ in year $t-1$, and $X_{i, j, t-1}$ is a vector of control variables. Year fixed effects are included to absorb the potential impact of global time-varying economic conditions. To control for serial correlation, we cluster the standard errors at the country-industry level.

Following Gompers et al (2008), we use industry lagged CAPEX scaled by total assets (from all public firms with data available in Worldscope /Compustat) and lagged industry median market-to-book ratio as control variables. As they argue, both public market valuations as well as perceived investment opportunities as measured by the market-to-book ratio might trigger response from venture capitalists. Because IPO markets provide an alternative exit channel for VC investors, we also include lagged measures of IPO activity as additional controls.

Table 3 displays results from these VC regressions. In Panel A we use the growth-based measure of $\mathrm{VC}$ activity defined in (2) as the dependent variable. In Panel B the dependent variable is based on the level of VC activity as defined in (1). Our main independent variable of interest, lagged M\&A activity, is constructed accordingly in terms of changes in Panel A and in terms of levels in Panel B. In both panels, specifications (1) to (4) are based on all 
VC deals, while specifications (5) to (8) include unique VC deals only. Because there are potentially large variations in lagged M\&A growth, we average M\&A growth over the last three years and use it as a dependent variable in Panel C.

Insert Table 3 Here

Results in Table 3 clearly indicate a positive association between various measures of VC intensity and lagged M\&A activity, consistent with our main hypothesis that an active takeover market provides more viable exit opportunities for venture capitalists and induces more investment by VC firms. Coefficients on lagged M\&A activity are positive and highly statistically significant in all but the last specification in column (8). Columns (4) and (8) have fewer observations as these specifications include the change in IPOs and some countries have had no IPOs and we thus exclude these countries. Coefficients in regressions that include all deals have similar magnitude than those in regressions with only unique deals, suggesting that improvements in the M\&A market not only result in more funding of new projects by VC firms, but also induce more follow-up investments by VC firms in their existing portfolio companies. Consistent with Gompers et al (2008), who interpret market-to-book ratio as a public signal about an industry's investment opportunities, we find a positive association between lagged industry market-to-book ratios and VC activity. Coefficients on industry market-to-book are positive and significant for level-based measures of VC intensity in Panel B and also significant in some specifications in Panel $\mathrm{C}$ that uses three year M\&A growth as a regressor. Note that unlike lagged M\&A intensity, lagged IPO intensity, while positive, is statistically insignificant in all specifications.

In the appendix (Table A1) we replicate results in Table 3 while excluding US deals. Table A1 shows that the results in Table 3 are not driven solely by US firms, but similar relations between $\mathrm{VC}$ and M\&A intensities are found in foreign countries as well. While coefficients on lagged growth in M\&A deals in panel A slightly decline in magnitude and lose significance in some specifications when excluding US data, the corresponding coefficients for level-based 
measures are highly significant in regressions on international data.

We also conduct additional robustness tests regarding the relation between M\&A and VC investments. We show in the appendix in Table A.3 that our results still hold if we treat investments by multiple VC firms as multiple deals. In Table A.4, we consider whether our results are driven by M\&A exits providing capital to new $\mathrm{VC}$ funds, and exclude first time funds as these VC firms may potentially be funded by M\&A exits. The positive relation between M\&A deals and VC investments still remains.

Overall, the results in Table 3 provide further evidence that M\&A and VC markets are interrelated and there is a positive association between VC activity and lagged M\&A intensity, consistent with Hypothesis 1.

\subsection{Analysis of $V C$ and $M E A$ waves}

There is a large literature that argues that many corporate types of activity are spread unevenly over time in wave-like patterns. ${ }^{6}$ There is also research that focuses on the relation between various corporate event waves. In particular, Dittmar and Dittmar (2008) study repurchases, equity issuance, and mergers and their response to GDP growth. Rau and Stouraitis (2011) examine the timing patterns of IPOs, SEOs, cash and stock financed acquisitions, as well as stock repurchases. Lyandres, Zhdanov, and Hsieh (2013) present a theory and evidence of the joint dynamics of IPO and M\&A activities. Celikyurt, Sevilir, and Shivdasani (2010) and Hovakimian and Hutton (2010) examine various motives for potential relation between $\mathrm{M} \& \mathrm{~A}$ and IPO waves.

In this section we follow this literature and complement our results in section 4.1 by identifying waves in both $\mathrm{VC}$ and $\mathrm{M} \& \mathrm{~A}$ markets and studying their joint time patterns. For the sake of completeness, we construct IPO waves as well. In doing so we follow Harford (2005) and construct wave indicators for VC, M\&A, and IPO intensities in the following way. We

\footnotetext{
${ }^{6}$ See, for example, Gompers et al (2008) for cyclicality of VC investments and Harford (2005) for analysis of merger waves in the US, Pastor and Veronesi (2005) for analysis of IPO waves , Harford (2005) and Maksimovic, Phillips and Yang (2013) for merger waves.
} 
first take the total number of deals in a country-industry and simulate 1,000 deal distributions by randomly assigning deals over time. We then calculate the highest two-year transaction concentration from each of the 1,000 draws and compare it to the actual concentration in the data. If the actual number of transactions in a two year period exceeds the 95th percentile from these simulated distributions, that period is identified as a wave. To make this analysis meaningful, we remove country-industries with less than 50 total deals and also remove those with time span between the first and last deal of less than 10 years in our data.

This procedure results in a sample of 7,799 country-industry years of VC activity, of which 1,168 years are identified as belonging to a wave, and 6,631 being outside of a wave. Activity in M\&A markets appears less volatile with only 865 country-industry years identified as wave years. The wave-like pattern of $\mathrm{VC}$ activities appears to materialize in most countries in our sample, however with some variation. Among countries with at least 200 industry-years in our dataset, the ones with the highest percentage of waves are Sweden, South Korea, China, and the United States (with overall percentage of wave years between $19.2 \%$ and 20.5\%) while the countries with the most stable VC market as measured by the presence of waves are Italy, Netherlands, and Japan (percentage of wave years between 9.2\% and 10.9\%). There is also considerable variation in the formation of waves in different industries (aggregated across countries). Business Services, Oil and Gas Extraction, and Electronic Equipment Industries have the most variability of VC activity as measured by the percentage of wave years, while Hotels, Furniture and Fixtures, and Home Furniture, Furnishings, And Equipment Stores have the least variability (among industries with at least 100 country-years).

To examine the relation between M\&A and VC waves, we use a logistic regression specification akin to that in (3) whereby the dependent variable is a dummy for a $\mathrm{VC}$ wave in a country-industry in a given year, and the main explanatory variable is a lagged M\&A wave dummy in the same country-industry. As before, we include year fixed effects and cluster standard errors by country-industry. We also include an industry's lagged median marketto-book ratio, lagged median CAPEX scaled by total assets, and lagged IPO wave dummy as control variables. Because we identify VC waves as periods of abnormally high two-year 
$\mathrm{VC}$ activity, there is a positive serial correlation in $\mathrm{VC}$ wave dummies, and we therefore also include the lagged $\mathrm{VC}$ wave dummy as an additional control variable.

Insert Table 4 Here

The results from these tests are presented in Table 4. As follows from this table, there is a strong positive association between contemporaneous and lagged $\mathrm{VC}$ waves. These results persist when including the lagged IPO wave variable. More importantly, coefficients on the lagged M\&A wave dummy are also positive and highly significantly related to the probability of a $\mathrm{VC}$ wave. Unconditionally, an M\&A wave in the previous year implies a probability of about $45 \%$ of having a $\mathrm{VC}$ wave in the next year. Conditional on observing a $\mathrm{VC}$ wave in the previous year, the existence of an M\&A wave in that year increases the probability of having a $\mathrm{VC}$ wave in the current year as well by about $19 \%$. Note that the predictive ability of lagged IPO waves is much weaker. The coefficients on the lagged IPO wave dummy are lower and statistically only marginally insignificant. In the appendix, we replicate this analysis while excluding US deals and find very similar results (see Table A2).

This evidence suggests that while there is clustering across time in both $\mathrm{VC}$ and M\&A markets, $\mathrm{VC}$ and $\mathrm{M} \& \mathrm{~A}$ waves tend to occur around the same time and past M\&A waves are a strong predictor of future $\mathrm{VC}$ waves. This result yields additional support for hypothesis 1 and further highlights the connectedness of M\&A and VC markets.

\subsection{Instrumenting cross-border $M \& A$ activity with currency depreciation}

While results in sections 4.1 and 4.2 strongly suggest that more active M\&A markets lead to intensified VC activity in the future, a potential concern is that both types of activity might be simultaneously driven by an exogenous economic shock. We alleviate this concern by including time fixed effects in our regressions and also lagging M\&A activity. To further mitigate this potential endogeneity concern, we follow an instrumental variable approach and 
instrument cross-border M\&A activity by depreciation of the local currency in the target country.

Erel, Liao, and Weisbach (2012) examine the determinants of cross-border mergers and find, among other things, that the change in the exchange rate between the acquirer and target countries' currencies prior to the merger is positively related to the probability of a merger. When the local currency in the target nation depreciates relative to that of the acquirer's nation, an acquisition becomes a more attractive deal from the valuation perspective. We therefore argue that a weaker currency makes local companies potentially cheaper acquisition targets for foreign acquirers and hence is likely to have a positive effect on cross-border M\&A activity. On the other hand, domestic VC investments are unlikely to be directly affected by the strength of local currency, because when local currency depreciates, local VC companies become subject to the same valuation shock. Hence, we argue that local currency depreciation is likely exogenous to domestic $\mathrm{VC}$ activity and we use a two-stage instrumental variable approach that uses local currency depreciation as an instrument for cross-border M\&A activity in the first stage. In the second stage we then regress our measure of $\mathrm{VC}$ intensity given by 1 on the measure of cross-border M\&A activity instrumented this way.

We obtain local currency rates for the 48 countries in our dataset from Thompson Reuters Datastream. In our tests we include year fixed effects to account for potential exogenous shocks that might affect both $\mathrm{VC}$ investments and M\&A deals. We also cluster standard errors at the country level to control for potential serial correlation in residuals. Because cross-border M\&A activity might be sensitive to the GDP growth in the target country, we include it as a control variable. As in (3) we include lagged median market-to-book ratio and lagged median investment in the target country as additional controls. In this exercise we do not focus on a particular acquirer country but argue that local currency depreciation is likely to attract more transactions from foreign acquirers in general. We therefore proxy for the local currency weakness by its depreciation relative to the United States dollar in the previous three years. As before, we examine the effect of instrumented cross-border M\&A activity on 
measures of $\mathrm{VC}$ intensity based on both total and unique $\mathrm{VC}$ deals.

Insert Table 5 Here

The results from these tests are presented in Table 5. As expected, the three-year currency depreciation in the target country is positively and significantly related to the volume of cross-border M\&A transactions. Furthermore, the instrumented cross-border M\&A activity is positive and significant when used to predict the total volume of domestic VC deals in the target country (column 2 in Table 5) as well as the volume of unique VC deals (column 3 in Table 5).

These results are consistent with our main premise that an increase in M\&A activity spurs more investment by $\mathrm{VC}$ firms as they sense better odds of a viable exit through an acquisition in the future. While weakening local currency has no direct effect on domestic VC deals, it does provides valuation incentives for foreign acquirers to engage in more M\&A deals that in turn have a positive effect on the VC market.

\section{The effect of country takeover laws on VC activity}

To further examine the effect of M\&A markets on the incentives of venture capitalists to engage in new deals and to further alleviate potential endogeneity concerns, we take advantage of the natural variation in takeover legislation and in the general friendliness of M\&A markets in different countries. In particular, we exploit an exogenous shock to takeover legislation in the form of staggered initiation of takeover acts. Takeover acts are laws passed specifically to foster takeover activity by reducing barriers to mergers and acquisition transactions. As Lel and Miller (2015) state, "They (country takeover laws) are aimed at reducing informational uncertainties regarding the legal framework applicable to M\&A transactions, thus simplifying the application of various laws in connection with M\&A transactions and streamlining M\&A procedures." We already control for potential endogeneity issues in various ways in section 
4. The country-level takeover laws provide a natural way to further alleviate these potential endogeneity concerns as long as they are passed by countries and are not driven by the VC industry. Lel and Miller (2015) study the effect of takeover laws on managerial discipline and CEO turnover. They find that following the passage of takeover laws, poorly performing firms experience more frequent takeovers and the propensity to replace poorly performing CEOs increases. Importantly for our analysis, they also found that the merger intensity increased after initiation of M\&A laws and particularly so for cross-border M\&A transactions. We focus on the role of takeover laws in stimulating $\mathrm{VC}$ activity. As M\&A conditions improve following enactment of those laws in different countries, we expect more investment by VC firms in those countries as they sense more viable exit opportunities through a takeover.

Table 6 shows the list of countries in our data that passed a takeover law sometime during the time span of our sample. Unfortunately, many developed countries passed a takeover law before 1985 (when our VC dataset starts), rendering enactment of such laws inadequate for our analysis. Some other countries (e.g. France and China) have not yet passed a takeover law.

While different across countries, the takeover laws have provisions aimed at simplifying M\&A transactions and fostering acquisition activity. For example, the 2002 Merger and Acquisition Act in Taiwan provided some general amendments to the Company Act to simplify the M\&A process, introduced more types of mergers including cash-out mergers and crossborder mergers, as well as provided some tax incentives to neutralize the transaction costs associated with M\&A deals. The Merger Act passed in 2004 in Switzerland regulates the civil law aspects of mergers in a broad comprehensive framework, significantly facilitating acquisition deals, which used to be governed by Swiss corporate law and had to be carried out through a series of complicated transactions, often triggering unfavorable tax consequences and formal liquidation procedures. In the case of Germany, the 2002 Takeover Act introduced formal provisions governing acquisition of publicly traded companies. As Strelow and Wildberger (2002) argue, prior to the passage of the act, takeovers of public companies had not 
often been considered an option worth pursuing. Table A.7 provides additional details about the specific features of takeover laws in different countries.

Insert Table 6 Here

To capture the effect of takeover laws on VC activity, we adopt a difference-in-difference methodology and define a POSTLAW dummy that indicates whether or not the country has a takeover law by year $t$. We set the POSTLAW dummy to one in the years following the enactment of takeover law in a country and set it to zero in the years before the enactment year and in all years in countries with no takeover law. Our empirical specification has the following form:

$$
V C_{i, j, t}=\alpha+\beta P O S T L A W_{i, t}+\delta X_{i, j, t-1}+v_{t}+\eta_{i}+\zeta_{j}+\varepsilon_{i, j, t}
$$

where $V C_{i, j, t}$ is a measure of $\mathrm{VC}$ activity in country $i$ and industry $j$ in year $t$ as in 1 , POSTLAW $W_{i, t}$ indicates whether a takeover law had been passed in country $i$ by year $t-1$, and $X_{i, j, t-1}$ is a vector of control variables. We include year fixed effects $v_{t}$ to absorb the potential impact of global time-varying economic conditions. We also include country $\eta_{i}$ and industry $\zeta_{j}$ fixed effects to account for potential exogenous drivers of VC activity at the country and industry level. To control for potential serial correlation in residuals, we cluster the standard errors at the country-industry level. As in our tests in section 4 we include median industry market-to-book ratio and median industry investment as control variables. In addition we also include median industry size and industry concentration as measured by the HerfindahlHirschman index constructed from sales. It is possible that VC investors find industries with a higher population of small firms potentially more attractive. It is also possible their investment decisions are sensitive to an industry's competitive structure. In addition, we also include two time dummy variables that indicate years one and two prior to the enactment of takeover laws to see if there is any time-trend in $\mathrm{VC}$ activity in pre-takeover law years. Finding such a trend would potentially undermine the causal relation between takeover laws and VC intensity. 
The empirical specification in 4 allows us to gauge the incremental effect of takeover law adoption on VC activity in countries that passed a takeover law (treatment countries) relative to those that did not (control countries). Furthermore, because different countries pass takeover laws at different times, the same country can act as both a treatment (if it already passed a law) and a control (if it did not). Performing this analysis at the industry level allows us to control for industry-level variables potentially related to the level of VC activity. Furthermore, industry fixed effects control for industry-specific unobservable differences.

The results from these tests are presented in Table 7. Panel A presents results for the measure of $\mathrm{VC}$ activity based on the total number of deals, while in panel B the dependent variable includes only unique $\mathrm{VC}$ deals.

Insert Table 7 Here

The results in Table 7 demonstrate that enactment of takeover laws has a favorable effect on subsequent VC activity in the country. Coefficients on the POSTLAW dummy are positive and significant in most specifications (and marginally significant in the others). This effect is common to the measures of $\mathrm{VC}$ activity based on both total and unique deals. Economically, the effect of POSTLAW dummy on VC activity is high - depending on the specification, a passage of a takeover law in a country leads to a 40\%-50\% increase in the VC intensity relative to countries that have not passed a takeover law. Overall these results render strong support for Hypothesis 2.

In addition, the results indicate that there are more takeover deals in industries with a smaller median size and more concentrated industries. Coefficients on the two PRELAW dummies are insignificant, suggesting that there is no evidence of a trend in VC activity in the two years prior to enactment of takeover laws.

Overall, the results in Table 7 demonstrate a positive response of VC investments to a positive shock to M\&A markets in the form of takeover law enactment and yield strong support for hypothesis 2 . 


\section{VC activity and state antitakeover laws}

While country-level takeover laws provide a natural setting to test for the effect of positive exogenous shocks to M\&A markets on venture capital investments, in this section we also take advantage of the state level shocks to M\&A environment in the US. In particular, we focus on state antitakeover laws in the US and their effect on VC activity.

State business combination laws impose a moratorium on certain kinds of transactions (e.g., asset sales, mergers) between a large shareholder and the firm for a period usually ranging between three and five years after the shareholder's stake passes a pre-specified (minority) threshold. We argue that there are multiple channels through which the business combination laws might affect VC investments. First, while intended to protect shareholders from hostile takeovers, business combination laws can potentially increase the cost to the acquiring firm and therefore have a negative effect on M\&A markets in general. Second, we argue that takeovers (including hostile ones) can result in more firm creation and hence VC funding as entrepreneurial employees leave to found new start-up companies. In a context of corporate bankruptcy, Babina (2016) shows that employer financial distress accelerates the exit of em-

ployees to create start-ups. Atanassov (2013) shows that antitakeover laws have a negative effect on a firm's innovation as measured by patent grants and citations. Phillips and Zhdanov (2013) show that an active acquisition market creates more incentives for entrepreneurs to innovate.

Atanassov (2013) studies the effect of state business combination antitakeover laws on innovation and finds a significant decline in the number of patents and citations per patent for firms incorporated in states that pass antitakeover laws relative to firms incorporated in states that do not. This is consistent with Phillips and Zhdanov (2013) who argue that there is a positive association between firms' innovation incentives and the friendliness of M\&A markets. In this section we extend his analysis by focusing on the effect of business combination antitakeover laws on $\mathrm{VC}$ investments in portfolio companies domiciled in the 
states that pass those laws. We expect that the general connectedness of M\&A and VC markets should lead to fewer VC deals in such states for the reasons discussed above.

We follow Atanassov (2013) in constructing a sample of state antitakeover laws. The dates of these laws are summarized in Table 8 . Out of the 50 states and the District of Columbia, 28 states passed an antitakeover law at some point in time. Other states never passed a business combination law. Most states passed those laws in late 1980s, with New York being the first state in our sample that passed a law (in 1985), and Nevada and Oklahoma being the last (both states passed antitakeover laws in 1991).

We believe that business combination laws are exogenous to VC activity because they are most likely outside of control of $\mathrm{VC}$ firms and also because they are often lobbied for by a specific company. For example, as pointed out by Romano (1987), in Connecticut the antitakeover law was promoted by Aetna, while in Arizona it was lobbied for by Greyhound.

We start our analysis by aggregating VC deals in US-based portfolio companies by state, resulting in a sample of 1,726 state-years. There is considerable dispersion in the VC activity across the states. Not surprisingly, states with most VC deals in our sample are California and Massachusetts (40,054 and 11,678 deals, respectively), followed by New York (6,746 deals) and Texas (5,917 deals), while the states with least deals are Alaska and Wyoming (4 and 14 deals, respectively). As before, to reduce the noise in the computation of the growth in VC deals, we remove state-year observations with less than five deals. This further reduces our sample to 1,126 state-years.

To formally test for the effect of business combination laws on subsequent VC intensity, we define a POSTLAW dummy, which we set equal to one in the years following the year of the law enactment in a state and set it to zero in the years prior to the enactment year. As in the previous section, we use a difference-in-difference methodology and estimate the following regression model:

$$
V C_{i, t}=\alpha+\beta P O S T L A W_{i, t}+\delta X_{i, t-1}+v_{t}+\varepsilon_{i, t},
$$


where $V C_{i, t}$ is a measure of $\mathrm{VC}$ activity in state $i$ in year $t, X_{i, t-1}$ is a vector of (lagged) control variables (aggregated at the state level), and $v_{t}$ are year fixed effects included to control for aggregate shocks to VC markets. We cluster standard errors by state to control for potential serial correlation in residuals. We use two measures of VC intensity - based on levels as in (1) and based on changes as in (2). Because in this section we are interested in the dynamics of $\mathrm{VC}$ deals at the state level, we measure growth in VC deals also at the state level.

Results from the state-level regressions of VC activity on the postlaw dummy are presented in Table 9. In Panel A we use our VC growth measure defined in (2) as the dependent variable. In Panel $\mathrm{B}$ the dependent variable is based on the level of $\mathrm{VC}$ activity as defined in (1). In both panels, regression specifications (1) and (3) use the percentage growth in all VC deals in the state as the dependent variable, while Specifications (2) and (4) include only unique VC deals.

\section{Insert Table 9 Here}

The results in Table 9 demonstrate that VC activity indeed slows down following enactments of state business combination laws in states that pass a law relative to those that do not. Coefficients on the POSTLAW dummy are negative and statistically significant in most specifications when controlling for size and pre-law dummies. The effect is also economically large. For example, the number of deals scaled by the number of public firms in the state declines by about $27 \%$ in post anti-takeover years in states that enact an antitakeover law relative to those that do not enact such a law.

Overall, consistent with our hypothesis 3, we see a negative association between enactment of state-level antitakeover business combination laws in the US and subsequent VC activity. This provides further evidence on the connectedness of M\&A and VC markets. 


\section{Robustness}

We perform a battery of checks to confirm the robustness of our main results from Tables 3-5 of the paper. In the interest of space these results are reported in the appendix.

\subsection{Excluding US deals}

A considerable chunk of our data comes from VC deals in the United States. In order to examine whether our results are not driven primarily by the US deals, we perform the same analysis as in Table 3 while excluding US VC transactions. The results from these international tests are reported in Table A.1. These results are consistent with our main results reported in Table 3. Coefficients on lagged M\&A activity are highly statistically significant in most specifications (marginally significant in some). The magnitude of coefficients is also similar (and slightly higher for non-US data).

We also replicate our analysis of VC waves while excluding US transactions. The results from these tests are presented in Table A.2 and are very similar to the main results reported in Table 4. Lagged M\&A waves are still a strong and highly significant predictor of VC waves. In contrast, coefficients on the lagged IPO, while positive, are statistically insignificant.

\subsection{Alternative deal definition}

In our main tests we consider investments by multiple VC firms in the same portfolio company on the same date as a single deal. To check the robustness of our results to this definition we replicate our main tests while treating investments by multiple VC firms as multiple deals (so we can see multiple deals for the same portfolio company on a single date). The results are presented in Table A.3 and show the robustness of our main results to this alternative definition of VC deals. Coefficients on lagged M\&A activity are positive and highly statistically significant in all specifications, both in level-based and change-based regressions. 


\subsection{Excluding new funds}

One potential concern might be that prior exits via M\&A may release capital that flows into new VC funds, leading to a positive relation between $\mathrm{VC}$ activity and past M\&A activity that we document. To alleviate this concern we repeat our analysis while excluding any funds that first appear in our database within one year prior to the transaction. The results from this test are reported in Table A.4 and are consistent with our main results.

\subsection{Instrumenting MESA activity with changes in the local treasury rates}

In this paper we address the potential endogeneity problem in various ways by including time fixed effects, instrumenting cross-border M\&A with local currency depreciations, and taking advantage of shocks to M\&A legislation both at a country level as well as at a state level in the US. In this appendix we follow an additional approach to address potential endogeneity. We argue that M\&A markets rely to a large extent on credit markets (Harford, 2005) and therefore M\&A activity is likely to slow down when credit market conditions deteriorate. On the other hand, there is no obvious direct link between credit markets and VC activity. We therefore use a two-stage instrumental variable approach. In the first stage, we instrument M\&A activity with a change in the local treasury rate. In the second stage we regress our measures of VC intensity on lagged instrumented M\&A.

We obtain local short-term treasury rates for the 48 countries in our dataset from Thompson Reuters Datastream. As in Table 5, we include year fixed effects and cluster standard errors at the country level. We also include GDP growth, lagged median market-to-book ratio, and lagged median investment in the target country as controls. The results from this IV approach are presented in Table A.5. As expected, there is a negative relation between changes in local treasury rates and M\&A activity. As credit market condition tighten, M\&A activity slows down. Furthermore, the instrumented M\&A activity is positive and significant in regressions with both total and unique $\mathrm{VC}$ deals. 


\subsection{Including horizontal mergers only}

It is conceivable that horizontal mergers (that involve a target and an acquirer from the same industry) are more relevant for $\mathrm{VC}$ professionals as they typically seek to sell out to a firm in the same line of business. For this reason we replicate our main results while including only takeover transactions in which the target and the aquirer belong to the same 2-digit SIC industry. The results from these tests are reported in Table A.6 and are generally very similar to our base case results in Table 3. Coefficients on lagged changes in M\&A activity are similar in magnitude (and statistically significant in most specifications) while coefficients on lagged levels of M\&A activity are higher (and also highly statisitcally significant), due to fewer horizontal takeovers.

\section{Conclusions}

We study how venture capital investments are related to past M\&A activity around the world. Our paper is the first to study the relation between VC and M\&A markets. We show that there is a strong positive association between venture capital and lagged M\&A activity around the world. We argue that growth in M\&A deals in a country is likely to attract more investments by VC firms as venture capitalists anticipate more viable future exit opportunities via a takeover. Consistent with this intuition, we first demonstrate a strong positive relation

between $\mathrm{VC}$ activity and lagged M\&A intensity. We reinforce this evidence by instrumenting cross-border M\&A intensity with the currency depreciation in the target country, and show that instrumented M\&A activity is associated with subsequent VC activity. We also examine the time patterns of $\mathrm{VC}$ and merger waves and document a strong association between the $\mathrm{VC}$ activity and merger waves.

We further show that takeover legislation has a subsequent impact on VC activity to further isolate the M\&A channel on $\mathrm{VC}$ activity. We exploit legislative changes to the ability and costs of undertaking M\&A both internationally and in the U.S. We take advantage of 
both positive and negative changes to the ability to undertake takeovers through government legislation. We examine pro-takeover legislation internationally and state-level anti-takeover legislation in the U.S. on subsequent VC activity. Following Lel and Miller (2015), we argue that an enactment of a country pro-takeover law represents a positive shock to M\&A activity. On the other hand, the passage of a state antitakeover law in the US can be interpreted a negative shock that is likely to reduce M\&A activity in that state. We show that subsequent VC activity responds to both types of shocks. First, the passage of a pro-takeover law in a country is associated with more subsequent VC deals in that country, while the enactment of a business combination antitakeover law in the US has a negative effect on subsequent VC investment.

Overall, our results highlight the importance of M\&A markets for the incentive to engage in VC. As many start-ups rely on VC funding and venture capitalists rely on acquisitions for subsequent exits, our results suggest that an active M\&A market is important for generating entrepreneurship and growth. 


\section{References}

Atanassov, J., 2013, "Do Hostile Takeovers Stifle Innovation? Evidence from Antitakeover Legislation and Corporate Patenting," Journal of Finance 68, 1097-1131.

Babina, T., 2017, "Destructive Creation at Work: How Financial Distress Spurs Entrepreneurship," Columbia University Working Paper 68, 1097-1131.

Baum, H., 2006, "Takeover Law in the EU and Germany: Comparative Analysis of a Regulatory Model," University of Tokyo Journal of Law and Politics 3, 60-72.

Bena, J. and K. Li, 2014, "Corporate Innovations and Mergers and Acquisitions," Journal of Finance 69, 1923-1960.

Bertrand, M. and S. Mullainathan, 2003, "Enjoying the Quiet Life? Corporate Governance and Managerial Preferences," Journal of Political Economy 111(5), pp.1043-1075.

Bhattacharya, U. and H. Daouk, 2002, "The World Price of Insider Trading," Journal of Finance 57(1), pp.75-108.

Celikyurt, U., M. Sevilir, and A. Shivdasani, 2010, "Going Public to Acquire: The Acquisition Motive in IPOs," Journal of Financial Economics 96, 4531-4552.

Dittmar, A. and R. Dittmar, 2008, "The Timing of Financing Decisions: An Examination of the Correlation in Financing Waves," Journal of Financial Economics 90, 59-83.

Erel, I., R.Liao, and M. Weisbach, 2012, "Determinants of Cross-Border Mergers and Acquisitions," Journal of Finance 67, 1045-1082.

Gilbert, R., 2007, "Competition and Innovation," in Wayne D. Collins (ed.), Issues in Competition Law and Policy, ABA Section of Antitrust Law.

Gilbert, R. and H. Greene, 2015, "Merging Innovation into Antitrust Agency Enforcement of the Clayton Act," forthcoming in Berkeley Technology Law Journal.

Giroud, X. and H. M. Mueller, 2010, "Does Corporate Governance Matter in Competitive Industries?" Journal of Financial Economics 95(3), 312-331.

Gompers, P. and J. Lerner, 2004, "The Venture Capital Cycle," MIT Press Cambridge, MA and London.

Gompers, P., A. Kovner, J. Lerner, and David Scharfstein, 2008, "Venture Capital Investment Cycles: The Impact of Public Markets," Journal of Financial Economics 87, 1-23.

Hall, B. H., 1999, "Mergers and R\&D Revisited," Working Paper, University of California at Berkeley.

Hellman, T. and M. Puri, 2002, "Venture Capital and the Professionalization of Start-up Firms: Empirical Evidence" Journal of Finance 57, 169-197. 
Hovakimian, A. and I. Hutton, 2010, "Merger-motivated IPOs," Financial Management 39, $1547-1573$.

Harford, J., 2005, "What Drives Merger Waves?" Journal of Financial Economics 77, 529560 .

Hecker, D., 1999, "High-Technology Employment: A Broader View," Monthly Labor Review $122,18-28$.

Iliev, P., K. Lins, D. Miller, and L. Roth, 2015, "Shareholder Voting and Corporate Governance Around the World " Review of Financial Studies, 28, 2167-2202.

Lel, U. and D. Miller, 2011, "Does Takeover Activity Cause Managerial Discipline? Evidence from International M\&A Laws," Review of Financial Studies 28, 1588-1622.

Lerner, J., A. Schoar, S. Sokolinski, and K. Wilson, 2016, "The Globalization of Angel Investments: Evidence Across Countries " Journal of Finance, forthcoming.

Lins, K., H. Servaes, and P. Tufano, 2010, "What Drives Corporate liquidity? An International Survey of Cash Holdings and Lines of Credit "Journal of Financial Economics, 98(1), 160-176.

Maksimovic, V., G. Phillips, and L. Yang, 2013, "Private and Public Merger Waves," Journal of Finance 68, 2177-2217.

Nenova, T., 2006, "Takeover Laws and Financial Development, " Working Paper No. 4029, World Bank Policy Research.

Phillips, G. and A. Zhdanov, 2013, "R\&D and the Incentives from Merger and Acquisition Activity," Review of Financial Studies 26, 34-78.

Poch, Peter, 1998, "Finally Takeover Rules in Austria," Mimeo, Ortner Pch Foramitti, Austria

Raghavendra , R. and A. Stouraitis, 2011, "Patterns in the Timing of Corporate Event Waves," Journal of Financial and Quantitative Analysis 46, 209-246.

Robinson, D. and B. Sensoy, 2016, "Cyclicality, Performance Measurement, and Cash Flow Liquidity in Private Equity, " Journal of Financial Economics 122, 521-543.

Romano, R., 1999, "The Political Economy of Takeover Statutes," Virginia Law Review 73, 111-199.

Rossi, F., 2012, "The Creation of Value for Shareholders in Tender Offers: An Empirical Investigation on the Italian Stock Market," China-USA Business Review 11, 1330-1343.

Schulz, N., 2007, "Review of the Literature on the Impact of Mergers on Innovation," working paper, University of Wuerzburg. 
Seru, A., 2104, "Firm Boundaries Matter: Evidence from Conglomerates and R\&D Activity," Journal of Financial Economics 111, 381-405.

Strelow , M. and J. Wildberger, 2002, "The New German Takeover Act," Journal of Private Equity 5, 53-56.

Waller, S. and M. Sag, 2015, "Promoting Innovation," Iowa Law Review 100, 2223-2247. 


\section{Figure 1}

$\mathrm{VC}$ and M\&A activities in the US and abroad

This figure presents the numbers of $\mathrm{VC}$ deals (both total and unique) and the numbers of M\&A deals over time. Graphs of VC activities are presented for deals in the US, the rest of the world, and separately in developed markets (as classified by MSCI, excluding US) and emerging/frontier markets.

Panel A: VC and M\&A activities in the US and the rest of the world
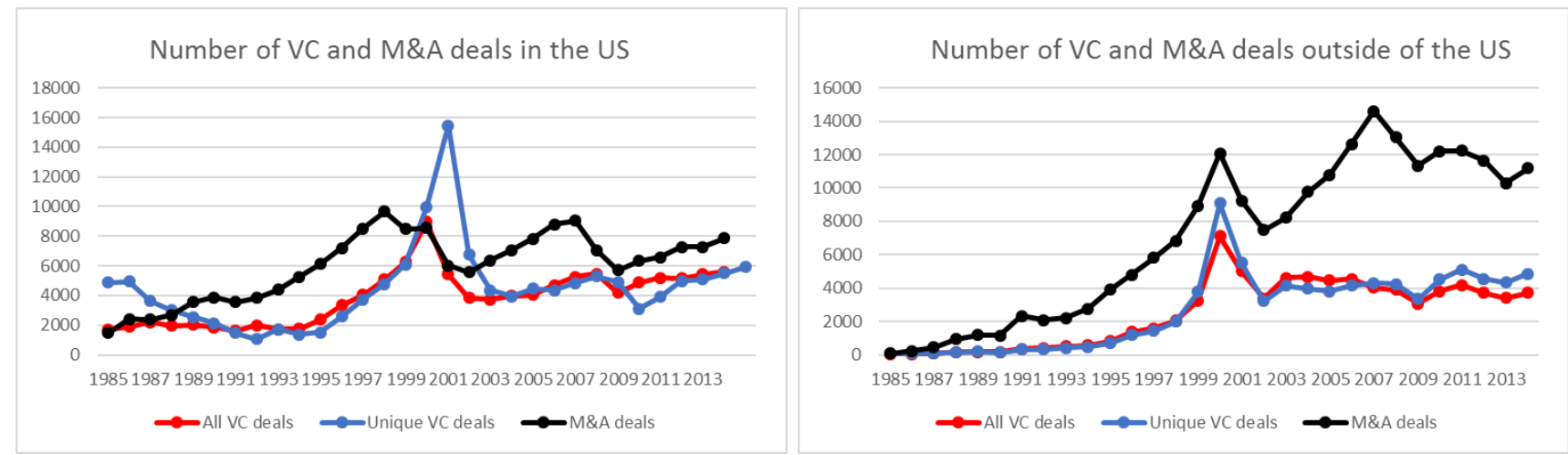

Panel B: VC and M\&A activities in developed (ex-US) and emerging/frontier markets
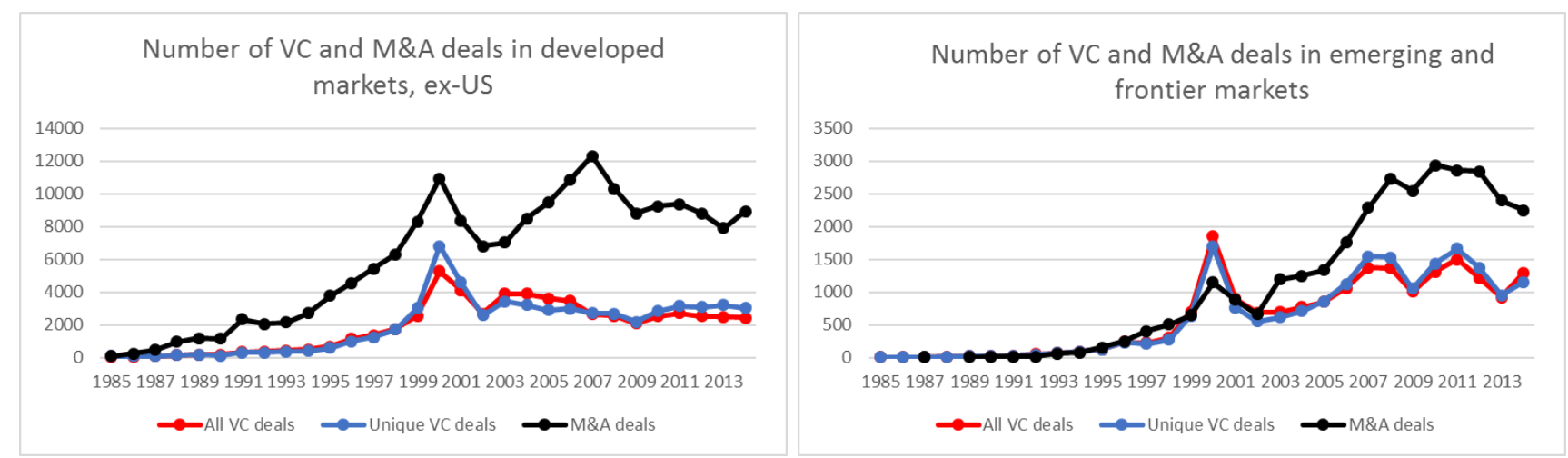
Table 1

DESCRIPTIVE STATISTICS

Table 1 presents the numbers of all VC deals, and takeover transactions by country. The sample period is 1985-2014.

\begin{tabular}{|c|c|c|c|}
\hline Country & $\begin{array}{l}\text { Number of } \mathrm{VC} \\
\text { deals }\end{array}$ & $\begin{array}{l}\text { Number of } \\
\text { unique VC deals }\end{array}$ & $\begin{array}{l}\text { Number of M\&A } \\
\text { deals }\end{array}$ \\
\hline Argentina & 128 & 160 & 495 \\
\hline Australia & 2355 & 1832 & 13178 \\
\hline Austria & 534 & 592 & 970 \\
\hline Belgium & 923 & 1163 & 1934 \\
\hline Bermuda & 99 & 84 & 86 \\
\hline Brazil & 772 & 835 & 2645 \\
\hline Canada & 15512 & 12595 & 22608 \\
\hline China & 8241 & 11475 & 9513 \\
\hline Czech Republic & 139 & 117 & 184 \\
\hline Denmark & 1180 & 1116 & 2436 \\
\hline Egypt & 59 & 69 & 81 \\
\hline Finland & 1947 & 1683 & 2726 \\
\hline France & 7142 & 9328 & 18297 \\
\hline Germany & 5092 & 6566 & 18663 \\
\hline Hong Kong & 471 & 565 & 2787 \\
\hline Hungary & 214 & 195 & 307 \\
\hline India & 3758 & 4101 & 4136 \\
\hline Indonesia & 112 & 160 & 235 \\
\hline Ireland & 1037 & 1198 & 1030 \\
\hline Israel & 1848 & 2653 & 703 \\
\hline Italy & 940 & 1046 & 5298 \\
\hline Japan & 1744 & 2338 & 12835 \\
\hline Kenya & 820 & 98 & 28 \\
\hline Luxembourg & 90 & 92 & 142 \\
\hline Malaysia & 190 & 214 & 2157 \\
\hline Mexico & 117 & 141 & 411 \\
\hline Morocco & 48 & 49 & 41 \\
\hline Netherlands & 1601 & 1641 & 5683 \\
\hline New Zealand & 240 & 233 & 1147 \\
\hline Nigeria & 98 & 104 & 48 \\
\hline Norway & 775 & 746 & 2143 \\
\hline Poland & 547 & 437 & 1138 \\
\hline Portugal & 569 & 459 & 548 \\
\hline Romania & 135 & 118 & 230 \\
\hline Russia & 581 & 684 & 4056 \\
\hline Singapore & 713 & 904 & 1699 \\
\hline South Africa & 171 & 194 & 966 \\
\hline South Korea & 4053 & 4247 & 2866 \\
\hline Spain & 1600 & 1843 & 6744 \\
\hline Sweden & 2618 & 2623 & 5920 \\
\hline Switzerland & 961 & 1212 & 2759 \\
\hline Taiwan & 509 & 624 & 413 \\
\hline Thailand & 145 & 155 & 233 \\
\hline Turkey & 93 & 108 & 460 \\
\hline United Kingdom & 9289 & 10030 & 49217 \\
\hline United States & 121338 & 139846 & 187709 \\
\hline Utd. Arab Em. & 89 & 110 & 215 \\
\hline Vietnam & 111 & 113 & 111 \\
\hline Total & 201010 & 226896 & 397871 \\
\hline
\end{tabular}


Table 2

Contemporaneous and lagged CORRElations of VC AND M\&A aCtivities.

Table 2 reports contemporaneous and lagged correlations between VC, M\&A, and IPO activities. \% change in VC deals $/ \%$ change in MEA deals /\% change in IPO deals is the difference between the number of VC /M\&A /IPO deals in the current and previous years divided by the total number of deals in the previous year. Scaled VC deals /Scaled MEGA deals /Scaled $I P O$ deals is the number of $\mathrm{VC} / \mathrm{M} \& \mathrm{~A} / \mathrm{IPO}$ deals divided by the total number of public firms in the same industry-year in the Worldscope (for international companies) and Compustat (for US companies) databases.

Panel A. Percentage growth in deals.

\begin{tabular}{|c|c|c|c|c|c|c|c|c|}
\hline & $\begin{array}{l}\% \\
\text { change } \\
\text { in VC } \\
\text { deals }\end{array}$ & $\begin{array}{l}\% \\
\text { change } \\
\text { in VC } \\
\text { deals } \\
(\mathrm{t}-1)\end{array}$ & $\begin{array}{l}\% \\
\text { change } \\
\text { in unique } \\
\text { VC deals }\end{array}$ & $\begin{array}{l}\% \\
\text { change } \\
\text { in unique } \\
\text { VC deals } \\
(\mathrm{t}-1)\end{array}$ & $\begin{array}{l}\% \\
\text { change } \\
\text { in M\&A } \\
\text { deals }\end{array}$ & $\begin{array}{l}\% \\
\text { change } \\
\text { in M\&A } \\
\text { deals } \\
(\mathrm{t}-1)\end{array}$ & $\begin{array}{l}\% \\
\text { change } \\
\text { in IPO } \\
\text { deals }\end{array}$ & $\begin{array}{l}\% \\
\text { change } \\
\text { in IPO } \\
\text { deals } \\
(\mathrm{t}-1)\end{array}$ \\
\hline$\%$ change in $\mathrm{VC}$ deals & 1.000 & & & & & & & \\
\hline$\%$ change in $\mathrm{VC}$ deals $(\mathrm{t}-1)$ & $\begin{array}{l}-0.195 \\
(0.000)\end{array}$ & 1.000 & & & & & & \\
\hline$\%$ change in unique $\mathrm{VC}$ deals & $\begin{array}{l}0.708 \\
(0.000)\end{array}$ & $\begin{array}{l}-0.159 \\
(0.000)\end{array}$ & 1.000 & & & & & \\
\hline$\%$ change in unique $\mathrm{VC}$ deals $(\mathrm{t}-1)$ & $\begin{array}{l}-0.105 \\
(0.000)\end{array}$ & $\begin{array}{l}0.738 \\
(0.000)\end{array}$ & $\begin{array}{l}-0.194 \\
(0.000)\end{array}$ & 1.000 & & & & \\
\hline$\%$ change in MA deals & $\begin{array}{l}0.094 \\
(0.000)\end{array}$ & $\begin{array}{l}0.039 \\
(0.005)\end{array}$ & $\begin{array}{l}0.089 \\
(0.000)\end{array}$ & $\begin{array}{l}0.018 \\
(0.201)\end{array}$ & 1.000 & & & \\
\hline$\%$ change in MA deals (t- 1 ) & $\begin{array}{l}0.051 \\
(0.000)\end{array}$ & $\begin{array}{l}0.092 \\
(0.000)\end{array}$ & $\begin{array}{l}0.061 \\
(0.001)\end{array}$ & $\begin{array}{l}0.086 \\
(0.000)\end{array}$ & $\begin{array}{l}-0.138 \\
(0.000)\end{array}$ & 1.000 & & \\
\hline$\%$ change in IPO deals & $\begin{array}{l}0.079 \\
(0.001)\end{array}$ & $\begin{array}{l}-0.016 \\
(0.516)\end{array}$ & $\begin{array}{l}0.092 \\
(0.000)\end{array}$ & $\begin{array}{l}-0.032 \\
(0.190)\end{array}$ & $\begin{array}{l}0.052 \\
(0.025)\end{array}$ & $\begin{array}{l}-0.012 \\
(0.608)\end{array}$ & 1.000 & \\
\hline$\%$ change in IPO deals (t- 1$)$ & $\begin{array}{l}0.028 \\
(0.252)\end{array}$ & $\begin{array}{l}0.085 \\
(0.000)\end{array}$ & $\begin{array}{l}0.009 \\
(0.701)\end{array}$ & $\begin{array}{l}0.089 \\
(0.000)\end{array}$ & $\begin{array}{l}0.074 \\
(0.001)\end{array}$ & $\begin{array}{l}0.083 \\
(0.001)\end{array}$ & $\begin{array}{l}-0.144 \\
(0.000)\end{array}$ & 1.000 \\
\hline
\end{tabular}

Panel B. Number of deals.

\begin{tabular}{|c|c|c|c|c|c|c|c|c|}
\hline & $\begin{array}{l}\text { Scaled } \\
\text { VC deals }\end{array}$ & $\begin{array}{l}\text { Scaled } \\
\text { VC deals } \\
(\mathrm{t}-1)\end{array}$ & $\begin{array}{l}\text { Scaled } \\
\text { unique } \\
\text { VC deals }\end{array}$ & $\begin{array}{l}\text { Scaled } \\
\text { unique } \\
\text { VC deals } \\
(\mathrm{t}-1)\end{array}$ & $\begin{array}{l}\text { Scaled } \\
\text { M\&A } \\
\text { deals }\end{array}$ & $\begin{array}{l}\text { Scaled } \\
\text { M\&A } \\
\text { deals } \\
(\mathrm{t}-1)\end{array}$ & $\begin{array}{l}\text { Scaled } \\
\text { IPO } \\
\text { deals }\end{array}$ & $\begin{array}{l}\text { Scaled } \\
\text { IPO } \\
\text { deals }(\mathrm{t}- \\
1)\end{array}$ \\
\hline Scaled VC deals & 1.000 & & & & & & & \\
\hline Scaled VC deals (t-1) & $\begin{array}{l}0.601 \\
(0.000)\end{array}$ & 1.000 & & & & & & \\
\hline Scaled unique VC deals & $\begin{array}{l}0.973 \\
(0.000)\end{array}$ & $\begin{array}{l}0.557 \\
(0.000)\end{array}$ & 1.000 & & & & & \\
\hline Scaled unique VC deals (t- 1 ) & $\begin{array}{l}0.594 \\
(0.000)\end{array}$ & $\begin{array}{l}0.975 \\
(0.000)\end{array}$ & $\begin{array}{l}0.590 \\
(0.000)\end{array}$ & 1.000 & & & & \\
\hline Scaled M\&A deals & $\begin{array}{l}0.540 \\
(0.000)\end{array}$ & $\begin{array}{l}0.276 \\
(0.000)\end{array}$ & $\begin{array}{l}0.543 \\
(0.000)\end{array}$ & $\begin{array}{l}0.285 \\
(0.000)\end{array}$ & 1.000 & & & \\
\hline Scaled M\&A deals (t-1) & $\begin{array}{l}0.345 \\
(0.000)\end{array}$ & $\begin{array}{l}0.571 \\
(0.000)\end{array}$ & $\begin{array}{l}0.353 \\
(0.000)\end{array}$ & $\begin{array}{l}0.576 \\
(0.000)\end{array}$ & $\begin{array}{l}0.606 \\
(0.000)\end{array}$ & 1.000 & & \\
\hline Scaled IPO deals & $\begin{array}{l}0.314 \\
(0.000)\end{array}$ & $\begin{array}{l}0.336 \\
(0.000)\end{array}$ & $\begin{array}{l}0.305 \\
(0.000)\end{array}$ & $\begin{array}{l}0.334 \\
(0.000)\end{array}$ & $\begin{array}{l}0.322 \\
(0.000)\end{array}$ & $\begin{array}{l}0.307 \\
(0.000)\end{array}$ & 1.000 & \\
\hline Scaled IPO deals (t-1) & $\begin{array}{l}0.276 \\
(0.000)\end{array}$ & $\begin{array}{l}0.314 \\
(0.000)\end{array}$ & $\begin{array}{l}0.254 \\
(0.000)\end{array}$ & $\begin{array}{l}0.306 \\
(0.000)\end{array}$ & $\begin{array}{l}0.196 \\
(0.000)\end{array}$ & $\begin{array}{l}0.327 \\
(0.000)\end{array}$ & $\begin{array}{l}0.675 \\
(0.000)\end{array}$ & 1.000 \\
\hline
\end{tabular}


Table 3

INDUSTRY-LEVEL REGRESSIONS OF VC INTENSITY.

Table $\mathrm{A} 3$ reports results from industry regressions of $\mathrm{VC}$ intensity on lagged $\mathrm{M} \& \mathrm{~A}$ intensity. \% change in $V C$ deals is the difference between the numbers of $\mathrm{VC}$ deals in the current and previous years divided by the number of deals in the previous year. \% change in MEA deals ( $t-1)$ is lagged percentage growth in the number of M\&A transactions. Industry Capex/TA $(t-1)$ is the lagged industry CAPEX scaled by total assets. Industry Market-to-Book (t-1) is lagged industry market-to-book ratio. \% change in unique $V C$ deals is the percentage growth in the number of unique VC deals. Scaled VC deals (Scaled $M E A$ deals) is the number of $\mathrm{VC}(\mathrm{M} \& \mathrm{~A})$ deals divided by the total number of public firms in the same industry-year in the Worldscope (for international companies) and Compustat (for US companies) databases. Standard errors are clustered by country-industry, year fixed effects are included.

Panel A. Dependent variable - growth in VC deals.

\begin{tabular}{|c|c|c|c|c|c|c|c|c|}
\hline & (1) & (2) & (3) & (4) & (5) & (6) & (7) & (8) \\
\hline & $\begin{array}{l}\% \\
\text { change } \\
\text { in VC } \\
\text { deals }\end{array}$ & $\begin{array}{l}\% \\
\text { change } \\
\text { in VC } \\
\text { deals }\end{array}$ & $\begin{array}{l}\% \\
\text { change } \\
\text { in VC } \\
\text { deals }\end{array}$ & $\begin{array}{l}\% \\
\text { change } \\
\text { in VC } \\
\text { deals }\end{array}$ & $\begin{array}{l}\% \\
\text { change } \\
\text { in } \\
\text { unique } \\
\text { VC } \\
\text { deals }\end{array}$ & $\begin{array}{l}\% \\
\text { change } \\
\text { in } \\
\text { unique } \\
\text { VC } \\
\text { deals }\end{array}$ & $\begin{array}{l}\% \\
\text { change } \\
\text { in } \\
\text { unique } \\
\text { VC } \\
\text { deals }\end{array}$ & $\begin{array}{l}\% \\
\text { change } \\
\text { in } \\
\text { unique } \\
\text { VC } \\
\text { deals }\end{array}$ \\
\hline$\%$ change in M\&A deals (t- 1 ) & $\begin{array}{l}0.042^{* *} \\
(0.017)\end{array}$ & $\begin{array}{l}0.050^{* *} \\
(0.021)\end{array}$ & $\begin{array}{l}0.051^{* *} \\
(0.022)\end{array}$ & $\begin{array}{l}0.109^{* *} \\
(0.042)\end{array}$ & $\begin{array}{l}0.086^{* * *} \\
(0.026)\end{array}$ & $\begin{array}{l}0.088^{* * *} \\
(0.029)\end{array}$ & $\begin{array}{l}0.088^{* * *} \\
(0.029)\end{array}$ & $\begin{array}{l}0.062 \\
(0.055)\end{array}$ \\
\hline Industry Capex/TA (t-1) & & $\begin{array}{l}0.236 \\
(0.231)\end{array}$ & $\begin{array}{l}0.741 \\
(0.686)\end{array}$ & $\begin{array}{l}0.262 \\
(1.038)\end{array}$ & & $\begin{array}{c}0.616^{* *} \\
(0.286)\end{array}$ & $\begin{array}{c}0.616^{* *} \\
(0.286)\end{array}$ & $\begin{array}{l}0.349 \\
(1.587)\end{array}$ \\
\hline Industry Market-to-Book (t-1) & & & $\begin{array}{l}0.001^{* * *} \\
(0.001)\end{array}$ & $\begin{array}{l}0.015 \\
(0.023)\end{array}$ & & & & $\begin{array}{l}0.037 \\
(0.023)\end{array}$ \\
\hline$\%$ change in IPOs $(\mathrm{t}-1)$ & & & & $\begin{array}{l}0.016 \\
(0.022)\end{array}$ & & & & $\begin{array}{l}0.013 \\
(0.030)\end{array}$ \\
\hline Observations & 5,589 & 5,113 & 5,039 & 1,611 & 5,310 & 4,867 & 4,867 & 1,585 \\
\hline R-squared & 0.061 & 0.058 & 0.059 & 0.088 & 0.045 & 0.046 & 0.046 & 0.097 \\
\hline Year fixed effects & Yes & Yes & Yes & Yes & Yes & Yes & Yes & Yes \\
\hline
\end{tabular}

Panel B. Dependent variable - number of deals scaled by the number of public firms

\begin{tabular}{|c|c|c|c|c|c|c|c|}
\hline (1) & (2) & (3) & (4) & (5) & (6) & (7) & (8) \\
\hline $\begin{array}{l}\text { scaled } \\
\text { vC } \\
\text { leals }\end{array}$ & $\begin{array}{l}\text { Scaled } \\
\text { VC } \\
\text { deals }\end{array}$ & $\begin{array}{l}\text { Scaled } \\
\text { VC } \\
\text { deals }\end{array}$ & $\begin{array}{l}\text { Scaled } \\
\text { VC } \\
\text { deals }\end{array}$ & $\begin{array}{l}\text { Scaled } \\
\text { unique } \\
\text { VC } \\
\text { deals }\end{array}$ & $\begin{array}{l}\text { Scaled } \\
\text { unique } \\
\text { VC } \\
\text { deals }\end{array}$ & $\begin{array}{l}\text { Scaled } \\
\text { unique } \\
\text { VC } \\
\text { deals }\end{array}$ & $\begin{array}{l}\text { Scaled } \\
\text { unique } \\
\text { VC } \\
\text { deals }\end{array}$ \\
\hline \multirow[t]{4}{*}{$\begin{array}{l}.223^{* * *} \\
(0.056)\end{array}$} & $\begin{array}{l}0.222^{* * *} \\
(0.056)\end{array}$ & $\begin{array}{l}0.194^{* * *} \\
(0.056)\end{array}$ & $\begin{array}{l}0.130^{*} \\
(0.072)\end{array}$ & $\begin{array}{l}0.278^{* * *} \\
(0.070)\end{array}$ & $\begin{array}{l}0.278^{* * *} \\
(0.071)\end{array}$ & $\begin{array}{l}0.239^{* * *} \\
(0.068)\end{array}$ & $\begin{array}{l}0.174^{*} \\
(0.089)\end{array}$ \\
\hline & $\begin{array}{l}2.841 \\
(1.959)\end{array}$ & $\begin{array}{l}2.291 \\
(1.953)\end{array}$ & $\begin{array}{l}0.165 \\
(2.508)\end{array}$ & & $\begin{array}{l}2.099 \\
(2.051)\end{array}$ & $\begin{array}{l}1.490 \\
(2.039)\end{array}$ & $\begin{array}{l}0.033 \\
(2.811)\end{array}$ \\
\hline & & $\begin{array}{l}0.156^{* *} \\
(0.060)\end{array}$ & $\begin{array}{l}0.297^{* *} \\
(0.135)\end{array}$ & & & $\begin{array}{l}0.242^{* * *} \\
(0.078)\end{array}$ & $\begin{array}{l}0.475^{* * *} \\
(0.171)\end{array}$ \\
\hline & & & $\begin{array}{l}0.272 \\
(0.222)\end{array}$ & & & & $\begin{array}{l}0.265 \\
(0.219)\end{array}$ \\
\hline 1,897 & 4,878 & 4,838 & 2,172 & 4,814 & 4,796 & 4,759 & 2,150 \\
\hline .125 & 0.127 & 0.121 & 0.174 & 0.135 & 0.136 & 0.136 & 0.190 \\
\hline Jec & Yes & Yes & Yes & Yes & Yes & Yes & Yes \\
\hline
\end{tabular}


Panel C. Using past 3-year growth in M\&A deals.

\begin{tabular}{|c|c|c|c|c|c|c|c|c|}
\hline & (1) & (2) & (3) & (4) & (5) & (6) & (7) & (8) \\
\hline & $\begin{array}{l}\% \\
\text { change } \\
\text { in VC } \\
\text { deals }\end{array}$ & $\begin{array}{l}\% \\
\text { change } \\
\text { in VC } \\
\text { deals }\end{array}$ & $\begin{array}{l}\% \\
\text { change } \\
\text { in VC } \\
\text { deals }\end{array}$ & $\begin{array}{l}\% \\
\text { change } \\
\text { in VC } \\
\text { deals }\end{array}$ & $\begin{array}{l}\% \\
\text { change } \\
\text { in } \\
\text { unique } \\
\text { VC } \\
\text { deals }\end{array}$ & $\begin{array}{l}\% \\
\text { change } \\
\text { in } \\
\text { unique } \\
\text { VC } \\
\text { deals }\end{array}$ & $\begin{array}{l}\% \\
\text { change } \\
\text { in } \\
\text { unique } \\
\text { VC } \\
\text { deals }\end{array}$ & $\begin{array}{l}\% \text { change } \\
\text { in unique } \\
\text { VC deals }\end{array}$ \\
\hline lagged 3 year $\%$ change in MA deals & $\begin{array}{l}0.089^{* * *} \\
(0.021)\end{array}$ & $\begin{array}{l}0.089^{* * *} \\
(0.023)\end{array}$ & $\begin{array}{l}0.087^{* * * *} \\
(0.023)\end{array}$ & $\begin{array}{l}0.054 \\
(0.036)\end{array}$ & $\begin{array}{l}0.081^{* * *} \\
(0.031)\end{array}$ & $\begin{array}{l}0.070^{* *} \\
(0.028)\end{array}$ & $\begin{array}{l}0.067^{* *} \\
(0.028)\end{array}$ & $\begin{array}{l}0.103^{* *} \\
(0.044)\end{array}$ \\
\hline Industry Capex/TA (t-1) & & $\begin{array}{l}0.489 \\
(0.511)\end{array}$ & $\begin{array}{l}0.628 \\
(0.524)\end{array}$ & $\begin{array}{l}-0.714 \\
(0.484)\end{array}$ & & $\begin{array}{l}0.019 \\
(0.711)\end{array}$ & $\begin{array}{l}0.204 \\
(0.725)\end{array}$ & $\begin{array}{l}-1.809^{* * *} \\
(0.557)\end{array}$ \\
\hline Industry Market-to-Book (t-1) & & & $\begin{array}{l}0.001^{* * *} \\
(0.000)\end{array}$ & $\begin{array}{l}0.022 \\
(0.021)\end{array}$ & & & $\begin{array}{l}0.005^{* * *} \\
(0.000)\end{array}$ & $\begin{array}{l}0.041^{*} \\
(0.024)\end{array}$ \\
\hline$\%$ change in IPOs $(\mathrm{t}-1)$ & & & & $\begin{array}{l}-0.002 \\
(0.029)\end{array}$ & & & & $\begin{array}{l}0.017 \\
(0.036)\end{array}$ \\
\hline Observations & 4,248 & 4,004 & 3,977 & 1,439 & 4,079 & 3,848 & 3,822 & 1,416 \\
\hline R-squared & 0.055 & 0.052 & 0.053 & 0.090 & 0.042 & 0.042 & 0.046 & 0.117 \\
\hline Year fixed effects & Yes & Yes & Yes & Yes & Yes & Yes & Yes & Yes \\
\hline
\end{tabular}


Table 4

WAVES IN VC AND M\&A ACTIVITIES.

Table 4 reports results from logistic regressions of the $\mathrm{VC}$ wave dummies on lagged M\&A and IPO wave dummies. Industry Capex/TA (t-1) is lagged industry CAPEX scaled by total assets. Industry Market-to-Book (t-1) is lagged industry market-to-book ratio. Standard errors are clustered by country-industry, year and country fixed effects are included. See Section 4 for details on construction of VC, M\&A, and IPO waves.

\begin{tabular}{|c|c|c|c|c|c|c|c|c|}
\hline & (1) & $(2)$ & $(3)$ & $(4)$ & $(5)$ & $(6)$ & (7) & $(8)$ \\
\hline & $\begin{array}{l}\mathrm{VC} \\
\text { wave }\end{array}$ & $\begin{array}{l}\mathrm{VC} \\
\text { wave }\end{array}$ & $\begin{array}{l}\mathrm{VC} \\
\text { wave }\end{array}$ & $\begin{array}{l}\mathrm{VC} \\
\text { wave }\end{array}$ & $\begin{array}{l}\mathrm{VC} \\
\text { wave }\end{array}$ & $\begin{array}{l}\mathrm{VC} \\
\text { wave }\end{array}$ & $\begin{array}{l}\mathrm{VC} \\
\text { wave }\end{array}$ & $\begin{array}{l}\mathrm{VC} \\
\text { wave }\end{array}$ \\
\hline Lagged M\&A wave & $\begin{array}{l}0.481^{* * *} \\
(0.031)\end{array}$ & $\begin{array}{l}0.191^{* * *} \\
(0.026)\end{array}$ & $\begin{array}{l}0.260^{* * *} \\
(0.039)\end{array}$ & $\begin{array}{l}0.480^{* * *} \\
(0.057)\end{array}$ & $\begin{array}{l}0.188^{* * *} \\
(0.044)\end{array}$ & $\begin{array}{l}0.481^{* * *} \\
(0.057)\end{array}$ & $\begin{array}{l}0.189^{* * *} \\
(0.044)\end{array}$ & $\begin{array}{l}0.269^{* * *} \\
(0.030)\end{array}$ \\
\hline Lagged VC wave & & $\begin{array}{l}0.575^{* * *} \\
(0.021)\end{array}$ & $\begin{array}{l}0.651^{* * *} \\
(0.023)\end{array}$ & & $\begin{array}{l}0.573^{* * *} \\
(0.033)\end{array}$ & & $\begin{array}{l}0.573^{* * *} \\
(0.034)\end{array}$ & $\begin{array}{l}0.652^{* * *} \\
(0.032)\end{array}$ \\
\hline Lagged IPO wave & & & $\begin{array}{l}0.081^{*} \\
(0.045)\end{array}$ & & & & & $\begin{array}{l}0.091^{*} \\
(0.052)\end{array}$ \\
\hline Industry Capex/TA (t-1) & & & & $\begin{array}{l}-0.000 \\
(0.305)\end{array}$ & $\begin{array}{l}0.142 \\
(0.169)\end{array}$ & $\begin{array}{l}0.053 \\
(0.344)\end{array}$ & $\begin{array}{l}0.204 \\
(0.222)\end{array}$ & $\begin{array}{l}0.234 \\
(0.277)\end{array}$ \\
\hline Industry Market-to-Book (t-1) & & & & & & $\begin{array}{l}-0.001 \\
(0.003)\end{array}$ & $\begin{array}{l}0.000 \\
(0.002)\end{array}$ & $\begin{array}{l}0.004 \\
(0.007)\end{array}$ \\
\hline Observations & 4,301 & 4,301 & 2,145 & 4,025 & 4,025 & 3,984 & 3,984 & 1,982 \\
\hline Year fixed effects & Yes & Yes & Yes & Yes & Yes & Yes & Yes & Yes \\
\hline Country fixed effects & Yes & Yes & Yes & Yes & Yes & Yes & Yes & Yes \\
\hline
\end{tabular}


Table 5

InSTRUMENTING CROSS-BORDER M\&A WITH THE EXCHANGE RATE

Table 5 reports results from two-stage IV regressions. In the first stage we instrument cross-border M\&A deals (scaled by the number of public firms) by the lagged 3-year change in the exchange rate. In the second stage with predict domestic VC deals with lagged instrumented CB M\&A deals. Year fixed effects are included, standard errors are clustered by country.

\begin{tabular}{llll}
\hline & \multicolumn{2}{c}{$(1)$} & \multicolumn{1}{c}{$(3)$} \\
& $\begin{array}{l}\text { Scaled CB } \\
\text { M\&A deals }\end{array}$ & $\begin{array}{l}\text { Scaled } \\
\text { deals }\end{array}$ & $\begin{array}{l}\text { Scaled } \\
\text { unique } \\
\text { deals }\end{array}$ \\
\hline 3-year change in exchange rate & $\begin{array}{l}2.562^{* * *} \\
(0.719)\end{array}$ & & \\
Median market-to-book & -0.002 & $0.974^{*}$ & $0.903^{*}$ \\
Median Investment & $(0.001)$ & $(0.544)$ & $(0.485)$ \\
GDP growth & 9.927 & $-30.196^{*}$ & $-28.012^{*}$ \\
& $(14.387)$ & $(16.722)$ & $(15.135)$ \\
Instrumented CB M\&A, lagged & $0.169^{* * *}$ & 0.085 & 0.066 \\
& $(0.060)$ & $(0.060)$ & $(0.048)$ \\
Observations & & $0.821^{* * *}$ & $0.747^{* *}$ \\
R-squared & 697 & $(0.300)$ & $(0.282)$ \\
Year fixed effects & 596 & 593 \\
\hline
\end{tabular}


Table 6

COUNTRIES With TAKEOVER LAWS

Table 6 reports the list of countries that passed a takeover law between 1980 and 2011.

\begin{tabular}{ll}
\hline \multicolumn{1}{c}{ Country } & Year of takeover law \\
\hline Austria & 1998 \\
Belgium & 1989 \\
Germany & 2002 \\
Finland & 1989 \\
India & 1997 \\
Indonesia & 1998 \\
Italy & 1992 \\
Ireland & 1997 \\
Malaysia & 1998 \\
New Zealand & 1993 \\
Spain & 1991 \\
Sweden & 1991 \\
Switzerland & 2004 \\
South Africa & 1991 \\
Taiwan & 2002 \\
\hline
\end{tabular}


Table 7

VC REGRESSIONS AND TAKEOVER LAWS

Table 7 reports results from industry regressions of VC intensity on the POSTLAW dummy. POSTLAW dummy is set to one if there was a takeover law in the country before, and to zero otherwise. Sales $H H I(t-1)$ is lagged Herfindahl index constructed from sales. Industry Capex/TA (t-1) is the lagged industry CAPEX scaled by total assets. Industry Market-toBook (t-1) is lagged industry market-to-book ratio. Median industry size (t-1) is the lagged median industry size. Prelaw $t(-1)$ dummy is set to one in the year preceding the takeover law year and to zero otherwise. Prelaw $t(-2)$ dummy is set to one in the year two years prior to the takeover law year and to zero otherwise. Country, industry, and year fixed effects included. Standard errors are clustered by country-industry.

Panel A. All VC deals.

\begin{tabular}{|c|c|c|c|c|c|c|}
\hline & $(1)$ & $(2)$ & $(3)$ & $(4)$ & $(5)$ & $(6)$ \\
\hline & $\begin{array}{l}\text { Scaled } \\
\text { VC deals }\end{array}$ & $\begin{array}{l}\text { Scaled } \\
\text { VC deals }\end{array}$ & $\begin{array}{l}\text { Scaled } \\
\text { VC deals }\end{array}$ & $\begin{array}{l}\text { Scaled } \\
\text { VC deals }\end{array}$ & $\begin{array}{l}\text { Scaled } \\
\text { VC deals }\end{array}$ & $\begin{array}{l}\text { Scaled } \\
\text { VC deals }\end{array}$ \\
\hline Postlaw dummy & $\begin{array}{l}0.501^{*} \\
(0.258)\end{array}$ & $\begin{array}{l}0.463^{* * *} \\
(0.169)\end{array}$ & $\begin{array}{l}0.514^{* * *} \\
(0.183)\end{array}$ & $\begin{array}{l}0.656^{* *} \\
(0.277)\end{array}$ & $\begin{array}{l}0.505^{* * *} \\
(0.175)\end{array}$ & $\begin{array}{l}0.564^{* * *} \\
(0.186)\end{array}$ \\
\hline Sales HHI (t-1) & & & $\begin{array}{l}1.238^{* * *} \\
(0.284)\end{array}$ & & & $\begin{array}{l}1.239^{* * *} \\
(0.284)\end{array}$ \\
\hline Industry Capex/TA (t-1) & & $\begin{array}{l}2.883 \\
(3.443)\end{array}$ & $\begin{array}{l}2.984 \\
(3.406)\end{array}$ & & $\begin{array}{l}2.891 \\
(3.445)\end{array}$ & $\begin{array}{l}2.994 \\
(3.408)\end{array}$ \\
\hline Industry Market-to-Book (t-1) & & $\begin{array}{l}0.020 \\
(0.030)\end{array}$ & $\begin{array}{l}0.018 \\
(0.028)\end{array}$ & & $\begin{array}{l}0.020 \\
(0.030)\end{array}$ & $\begin{array}{l}0.018 \\
(0.028)\end{array}$ \\
\hline Median industry size (t-1) & & $\begin{array}{l}0.038 \\
(0.046)\end{array}$ & $\begin{array}{l}0.083^{*} \\
(0.045)\end{array}$ & & $\begin{array}{l}0.038 \\
(0.046)\end{array}$ & $\begin{array}{l}0.083^{*} \\
(0.045)\end{array}$ \\
\hline Prelaw t(-1) dummy & & & & $\begin{array}{l}0.358 \\
(0.261)\end{array}$ & $\begin{array}{l}0.129 \\
(0.163)\end{array}$ & $\begin{array}{l}0.133 \\
(0.181)\end{array}$ \\
\hline Prelaw t(-2) dummy & & & & $\begin{array}{l}0.464 \\
(0.305)\end{array}$ & $\begin{array}{l}0.108 \\
(0.144)\end{array}$ & $\begin{array}{l}0.149 \\
(0.152)\end{array}$ \\
\hline Observations & 4,865 & 3,870 & 3,870 & 4,865 & 3,870 & 3,870 \\
\hline R-squared & 0.250 & 0.282 & 0.288 & 0.250 & 0.282 & 0.288 \\
\hline Year fixed effects & Yes & Yes & Yes & Yes & Yes & Yes \\
\hline Country fixed effects & Yes & Yes & Yes & Yes & Yes & Yes \\
\hline Industry fixed effects & Yes & Yes & Yes & Yes & Yes & Yes \\
\hline
\end{tabular}


Panel B. Only unique VC deals.

\begin{tabular}{|c|c|c|c|c|c|c|}
\hline & (1) & $(2)$ & $(3)$ & (4) & $(5)$ & $(6)$ \\
\hline & $\begin{array}{l}\text { Scaled } \\
\text { unique } \\
\text { VC deals }\end{array}$ & $\begin{array}{l}\text { Scaled } \\
\text { unique } \\
\text { VC deals }\end{array}$ & $\begin{array}{l}\text { Scaled } \\
\text { unique } \\
\text { VC deals }\end{array}$ & $\begin{array}{l}\text { Scaled } \\
\text { unique } \\
\text { VC deals }\end{array}$ & $\begin{array}{l}\text { Scaled } \\
\text { unique } \\
\text { VC deals }\end{array}$ & $\begin{array}{l}\text { Scaled } \\
\text { unique } \\
\text { VC deals }\end{array}$ \\
\hline Postlaw dummy & $\begin{array}{l}0.697^{* *} \\
(0.307)\end{array}$ & $\begin{array}{l}0.551^{* *} \\
(0.225)\end{array}$ & $\begin{array}{l}0.607^{* *} \\
(0.240)\end{array}$ & $\begin{array}{l}0.818^{* * *} \\
(0.316)\end{array}$ & $\begin{array}{l}0.586^{* * *} \\
(0.225)\end{array}$ & $\begin{array}{l}0.660^{* * *} \\
(0.238)\end{array}$ \\
\hline Sales HHI (t-1) & & & $\begin{array}{l}1.236^{* * *} \\
(0.304)\end{array}$ & & & $\begin{array}{l}1.237^{* * *} \\
(0.305)\end{array}$ \\
\hline Industry Capex/TA (t-1) & & $\begin{array}{l}2.497 \\
(3.423)\end{array}$ & $\begin{array}{l}2.499 \\
(3.396)\end{array}$ & & $\begin{array}{l}2.502 \\
(3.425)\end{array}$ & $\begin{array}{l}2.506 \\
(3.398)\end{array}$ \\
\hline Industry Market-to-Book (t-1) & & $\begin{array}{l}0.022 \\
(0.019)\end{array}$ & $\begin{array}{l}0.021 \\
(0.018)\end{array}$ & & $\begin{array}{l}0.022 \\
(0.019)\end{array}$ & $\begin{array}{l}0.021 \\
(0.018)\end{array}$ \\
\hline Medium industry size (t-1) & & $\begin{array}{l}0.038 \\
(0.047)\end{array}$ & $\begin{array}{l}0.084^{*} \\
(0.045)\end{array}$ & & $\begin{array}{l}0.038 \\
(0.047)\end{array}$ & $\begin{array}{l}0.084^{*} \\
(0.045)\end{array}$ \\
\hline Prelaw t(-1) dummy & & & & $\begin{array}{l}0.168 \\
(0.293)\end{array}$ & $\begin{array}{l}0.107 \\
(0.195)\end{array}$ & $\begin{array}{l}0.132 \\
(0.206)\end{array}$ \\
\hline Prelaw t(-2) dummy & & & & $\begin{array}{l}0.488 \\
(0.334)\end{array}$ & $\begin{array}{l}0.102 \\
(0.174)\end{array}$ & $\begin{array}{l}0.176 \\
(0.172)\end{array}$ \\
\hline Observations & 5,535 & 4,308 & 4,308 & 5,535 & 4,308 & 4,308 \\
\hline R-squared & 0.239 & 0.278 & 0.283 & 0.239 & 0.278 & 0.283 \\
\hline Year fixed effects & Yes & Yes & Yes & Yes & Yes & Yes \\
\hline Country fixed effects & Yes & Yes & Yes & Yes & Yes & Yes \\
\hline Industry fixed effects & Yes & Yes & Yes & Yes & Yes & Yes \\
\hline
\end{tabular}


Table 8

State ANTITAKEOVER BUSINESS COMBINATION LAWS

Table 8 presents the years of enactment of business combination laws by state.

\begin{tabular}{|c|c|}
\hline State & Year of law enactment \\
\hline Alabama & - \\
\hline Alaska & - \\
\hline Arizona & 1987 \\
\hline Arkansas & - \\
\hline California & - \\
\hline Colorado & - \\
\hline Connecticut & 1989 \\
\hline District of Columbia & - \\
\hline Delaware & 1988 \\
\hline Florida & - \\
\hline Georgia & 1988 \\
\hline Hawaii & - \\
\hline Idaho & 1988 \\
\hline Illinois & 1989 \\
\hline Indiana & - \\
\hline Iowa & - \\
\hline Kansas & - \\
\hline Kentucky & 1987 \\
\hline Louisiana & - \\
\hline Maine & 1988 \\
\hline Maryland & 1989 \\
\hline Massachusetts & 1989 \\
\hline Michigan & 1989 \\
\hline Minnesota & 1987 \\
\hline Mississippi & - \\
\hline Missouri & 1986 \\
\hline Montana & - \\
\hline Nebraska & 1988 \\
\hline Nevada & 1991 \\
\hline \multicolumn{2}{|l|}{ New Hampshire } \\
\hline New Jersey & 1986 \\
\hline New Mexico & - \\
\hline New York & 1985 \\
\hline North Carolina & - \\
\hline North Dakota & - \\
\hline Ohio & 1990 \\
\hline Oklahoma & 1991 \\
\hline Oregon & - \\
\hline Pennsylvania & 1989 \\
\hline Rhode Island & 1990 \\
\hline South Carolina & 1988 \\
\hline South Dakota & 1990 \\
\hline Tennessee & 1988 \\
\hline Texas & - \\
\hline Utah & - \\
\hline Vermont & - \\
\hline Virginia & 1988 \\
\hline Washington & 1987 \\
\hline West Virginia & - \\
\hline Wisconsin & 1987 \\
\hline Wyoming & 1989 \\
\hline
\end{tabular}


Table 9

STATE-LEVEL REGRESSIONS ON STATE ANTITAKEOVER LAW DUMMY

Table 9 reports results from state level regressions of VC intensity on the POSTLAW dummy. POSTLAW dummy is set to 1 in a state after the antitakeover law is enacted. Median CAPEX/TA (t-1) is the lagged median firm CAPEX scaled by total assets in the state. Median Market-to-Book (t-1) is lagged median market-to-book ratio. Median size (t-1) is the lagged median firm size. Year fixed effects are included, errors are clustered by state.

Panel A. Dependent variable number of VC deals scaled by number of public firms in a state.

\begin{tabular}{|c|c|c|c|c|c|c|}
\hline & (1) & $(2)$ & $(3)$ & $(4)$ & $(5)$ & (6) \\
\hline & $\begin{array}{l}\text { Scaled VC } \\
\text { deals }\end{array}$ & $\begin{array}{l}\text { Scaled } \\
\text { unique VC } \\
\text { deals }\end{array}$ & $\begin{array}{l}\text { Scaled VC } \\
\text { deals }\end{array}$ & $\begin{array}{l}\text { Scaled } \\
\text { unique VC } \\
\text { deals }\end{array}$ & $\begin{array}{l}\text { Scaled VC } \\
\text { deals }\end{array}$ & $\begin{array}{l}\text { Scaled } \\
\text { unique VC } \\
\text { deals }\end{array}$ \\
\hline Postlaw dummy & $\begin{array}{l}-0.226^{*} \\
(0.117)\end{array}$ & $\begin{array}{l}-0.262^{*} \\
(0.147)\end{array}$ & $\begin{array}{l}-0.251^{* *} \\
(0.110)\end{array}$ & $\begin{array}{l}-0.285^{* *} \\
(0.133)\end{array}$ & $\begin{array}{l}-0.253^{* *} \\
(0.111)\end{array}$ & $\begin{array}{l}-0.288^{* *} \\
(0.134)\end{array}$ \\
\hline Median CAPEX/TA (t-1) & & & $\begin{array}{l}-4.737^{* *} \\
(1.830)\end{array}$ & $\begin{array}{l}-6.500^{* * *} \\
(2.153)\end{array}$ & $\begin{array}{l}-4.745^{* *} \\
(1.823)\end{array}$ & $\begin{array}{l}-6.510^{* * *} \\
(2.136)\end{array}$ \\
\hline Median Market-to-Book (t-1) & & & $\begin{array}{l}0.196 \\
(0.213)\end{array}$ & $\begin{array}{l}0.179 \\
(0.323)\end{array}$ & $\begin{array}{l}0.196 \\
(0.213)\end{array}$ & $\begin{array}{l}0.180 \\
(0.324)\end{array}$ \\
\hline Median Size (t-1) & & & $\begin{array}{l}0.000 \\
(0.000)\end{array}$ & $\begin{array}{l}0.000 \\
(0.000)\end{array}$ & $\begin{array}{l}0.000 \\
(0.000)\end{array}$ & $\begin{array}{l}0.000 \\
(0.000)\end{array}$ \\
\hline Prelaw t(-1) dummy & & & & & $\begin{array}{l}-0.117^{*} \\
(0.059)\end{array}$ & $\begin{array}{l}-0.197^{*} \\
(0.105)\end{array}$ \\
\hline Prelaw t(-2) dummy & & & & & $\begin{array}{l}-0.046 \\
(0.061)\end{array}$ & $\begin{array}{l}-0.124 \\
(0.116)\end{array}$ \\
\hline Observations & 1,084 & 1,083 & 1,084 & 1,083 & 1,084 & 1,083 \\
\hline R-squared & 0.296 & 0.240 & 0.328 & 0.276 & 0.329 & 0.277 \\
\hline Year fixed effects & Yes & Yes & Yes & Yes & Yes & Yes \\
\hline
\end{tabular}


Panel B. Dependent variable growth in the number of VC deals.

\begin{tabular}{|c|c|c|c|c|c|c|}
\hline & $(1)$ & $(2)$ & $(3)$ & $(4)$ & $(5)$ & (6) \\
\hline & $\begin{array}{l}\% \text { change in } \\
\text { VC deals }\end{array}$ & $\begin{array}{l}\% \text { change in } \\
\text { unique VC } \\
\text { deals }\end{array}$ & $\begin{array}{l}\% \text { change in } \\
\text { VC deals }\end{array}$ & $\begin{array}{l}\% \text { change in } \\
\text { unique VC } \\
\text { deals }\end{array}$ & $\begin{array}{l}\% \text { change in } \\
\text { VC deals }\end{array}$ & $\begin{array}{l}\% \text { change in } \\
\text { unique VC } \\
\text { deals }\end{array}$ \\
\hline Postlaw dummy & $\begin{array}{l}-0.141^{* *} \\
(0.055)\end{array}$ & $\begin{array}{l}-0.169^{* *} \\
(0.073)\end{array}$ & $\begin{array}{l}-0.129^{* *} \\
(0.054)\end{array}$ & $\begin{array}{l}-0.159^{* *} \\
(0.075)\end{array}$ & $\begin{array}{l}-0.130^{* *} \\
(0.056)\end{array}$ & $\begin{array}{l}-0.160^{* *} \\
(0.076)\end{array}$ \\
\hline Median CAPEX/TA (t-1) & & & $\begin{array}{l}0.413 \\
(1.445)\end{array}$ & $\begin{array}{l}1.086 \\
(1.783)\end{array}$ & $\begin{array}{l}0.419 \\
(1.448)\end{array}$ & $\begin{array}{l}1.088 \\
(1.779)\end{array}$ \\
\hline Median Market-to-Book (t-1) & & & $\begin{array}{l}-0.193^{* *} \\
(0.081)\end{array}$ & $\begin{array}{l}-0.217 \\
(0.147)\end{array}$ & $\begin{array}{l}-0.195^{* *} \\
(0.082)\end{array}$ & $\begin{array}{l}-0.218 \\
(0.148)\end{array}$ \\
\hline Median Size (t-1) & & & $\begin{array}{l}0.000 \\
(0.000)\end{array}$ & $\begin{array}{l}-0.000 \\
(0.000)\end{array}$ & $\begin{array}{l}0.000 \\
(0.000)\end{array}$ & $\begin{array}{l}-0.000 \\
(0.000)\end{array}$ \\
\hline Prelaw t(-1) dummy & & & & & $\begin{array}{l}0.006 \\
(0.215)\end{array}$ & $\begin{array}{l}-0.019 \\
(0.254)\end{array}$ \\
\hline Prelaw t(-2) dummy & & & & & $\begin{array}{l}-0.225 \\
(0.144)\end{array}$ & $\begin{array}{l}-0.108 \\
(0.150)\end{array}$ \\
\hline Observations & 1,095 & 1,088 & 1,095 & 1,088 & 1,095 & 1,088 \\
\hline R-squared & 0.253 & 0.244 & 0.263 & 0.249 & 0.264 & 0.249 \\
\hline Year fixed effects & Yes & Yes & Yes & Yes & Yes & Yes \\
\hline
\end{tabular}


Table A1

INDUSTRY-LEVEL REGRESSIONS OF VC INTENSITY ON NON-US DATA.

Table A1 reports results from industry regressions of VC intensity on lagged M\&A intensity using international data only (excluding the US). \% change in VC deals is the difference between the numbers of VC deals in the current and previous years divided by the number of deals in the previous year. \% change in $M \mathscr{E} A$ deals (t-1) is lagged percentage growth in the number of M\&A transactions. Industry Capex/TA (t-1) is the lagged industry CAPEX scaled by total assets. Industry Market-toBook ( $t$-1) is lagged industry market-to-book ratio. \% change in unique $V C$ deals is the percentage growth in the number of unique VC deals. Scaled VC deals (Scaled MEAA deals) is the number of VC (M\&A) deals divided by the total number of public firms in the same industry-year in the Worldscope database. Standard errors are clustered by country-industry, year fixed effects are included.

Panel A. Dependent variable - growth in VC deals.

\begin{tabular}{|c|c|c|c|c|c|c|c|c|}
\hline & (1) & (2) & (3) & (4) & (5) & (6) & (7) & (8) \\
\hline & $\begin{array}{l}\% \\
\text { change } \\
\text { in VC } \\
\text { deals }\end{array}$ & $\begin{array}{l}\% \\
\text { change } \\
\text { in VC } \\
\text { deals }\end{array}$ & $\begin{array}{l}\% \\
\text { change } \\
\text { in VC } \\
\text { deals }\end{array}$ & $\begin{array}{l}\% \\
\text { change } \\
\text { in VC } \\
\text { deals }\end{array}$ & $\begin{array}{l}\% \\
\text { change } \\
\text { in } \\
\text { unique } \\
\text { VC } \\
\text { deals }\end{array}$ & $\begin{array}{l}\% \\
\text { change } \\
\text { in } \\
\text { unique } \\
\text { VC } \\
\text { deals }\end{array}$ & $\begin{array}{l}\% \\
\text { change } \\
\text { in } \\
\text { unique } \\
\text { VC } \\
\text { deals }\end{array}$ & $\begin{array}{l}\% \\
\text { change } \\
\text { in } \\
\text { unique } \\
\text { VC } \\
\text { deals }\end{array}$ \\
\hline$\%$ change in M\&A deals (t- 1 ) & $\begin{array}{l}0.041^{*} \\
(0.022)\end{array}$ & $\begin{array}{l}0.053^{* *} \\
(0.027)\end{array}$ & $\begin{array}{l}0.055^{*} \\
(0.028)\end{array}$ & $\begin{array}{l}0.091^{*} \\
(0.052)\end{array}$ & $\begin{array}{l}0.070^{*} \\
(0.036)\end{array}$ & $\begin{array}{l}0.069^{*} \\
(0.041)\end{array}$ & $\begin{array}{l}0.069^{*} \\
(0.041)\end{array}$ & $\begin{array}{l}0.029 \\
(0.061)\end{array}$ \\
\hline Industry Capex/TA (t-1) & & $\begin{array}{l}0.493 \\
(0.842)\end{array}$ & $\begin{array}{l}0.719 \\
(1.037)\end{array}$ & $\begin{array}{l}-0.012 \\
(1.638)\end{array}$ & & $\begin{array}{l}0.995 \\
(1.194)\end{array}$ & $\begin{array}{l}0.995 \\
(1.194)\end{array}$ & $\begin{array}{l}0.542 \\
(2.529)\end{array}$ \\
\hline Industry Market-to-Book (t-1) & & & $\begin{array}{l}0.013^{* *} \\
(0.006)\end{array}$ & $\begin{array}{l}-0.006 \\
(0.022)\end{array}$ & & & & $\begin{array}{l}0.023 \\
(0.026)\end{array}$ \\
\hline$\%$ change in IPOs (t-1) & & & & $\begin{array}{l}0.013 \\
(0.027)\end{array}$ & & & & $\begin{array}{l}0.017 \\
(0.039)\end{array}$ \\
\hline Observations & 3,567 & 3,207 & 3,145 & 877 & 3,421 & 3,076 & 3,076 & 865 \\
\hline R-squared & 0.093 & 0.094 & 0.097 & 0.123 & 0.073 & 0.076 & 0.076 & 0.115 \\
\hline Year fixed effects & Yes & Yes & Yes & Yes & Yes & Yes & Yes & Yes \\
\hline
\end{tabular}

Panel B. Dependent variable - number of deals scaled by the number of public firms.

\begin{tabular}{|c|c|c|c|c|c|c|c|c|}
\hline & (1) & $(2)$ & $(3)$ & (4) & $(5)$ & (6) & (7) & (8) \\
\hline & $\begin{array}{l}\text { Scaled } \\
\text { VC } \\
\text { deals }\end{array}$ & $\begin{array}{l}\text { Scaled } \\
\text { VC } \\
\text { deals }\end{array}$ & $\begin{array}{l}\text { Scaled } \\
\text { VC } \\
\text { deals }\end{array}$ & $\begin{array}{l}\text { Scaled } \\
\text { VC } \\
\text { deals }\end{array}$ & $\begin{array}{l}\text { Scaled } \\
\text { unique } \\
\text { VC } \\
\text { deals }\end{array}$ & $\begin{array}{l}\text { Scaled } \\
\text { unique } \\
\text { VC } \\
\text { deals }\end{array}$ & $\begin{array}{l}\text { Scaled } \\
\text { unique } \\
\text { VC } \\
\text { deals }\end{array}$ & $\begin{array}{l}\text { Scaled } \\
\text { unique } \\
\text { VC } \\
\text { deals }\end{array}$ \\
\hline Scaled M\&A deals (t-1) & $\begin{array}{l}0.313^{* * *} \\
(0.056)\end{array}$ & $\begin{array}{l}0.310^{* * *} \\
(0.057)\end{array}$ & $\begin{array}{l}0.290^{* * *} \\
(0.065)\end{array}$ & $\begin{array}{l}0.202^{* *} \\
(0.084)\end{array}$ & $\begin{array}{l}0.393^{* * *} \\
(0.070)\end{array}$ & $\begin{array}{l}0.393^{* * *} \\
(0.071)\end{array}$ & $\begin{array}{l}0.357^{* * *} \\
(0.076)\end{array}$ & $\begin{array}{l}0.271^{* * *} \\
(0.100)\end{array}$ \\
\hline Industry Capex/TA (t-1) & & $\begin{array}{l}2.940 \\
(2.831)\end{array}$ & $\begin{array}{l}2.433 \\
(2.879)\end{array}$ & $\begin{array}{l}-0.242 \\
(3.735)\end{array}$ & & $\begin{array}{l}1.641 \\
(2.937)\end{array}$ & $\begin{array}{l}1.155 \\
(2.945)\end{array}$ & $\begin{array}{l}-0.446 \\
(4.140)\end{array}$ \\
\hline Industry Market-to-Book (t-1) & & & $\begin{array}{l}0.142^{*} \\
(0.076)\end{array}$ & $\begin{array}{l}0.278^{*} \\
(0.156)\end{array}$ & & & $\begin{array}{l}0.244^{* *} \\
(0.096)\end{array}$ & $\begin{array}{l}0.465^{* *} \\
(0.196)\end{array}$ \\
\hline Scaled IPO deals (t-1) & & & & $\begin{array}{l}0.209 \\
(0.197)\end{array}$ & & & & $\begin{array}{l}0.181 \\
(0.177)\end{array}$ \\
\hline Observations & 2,919 & 2,905 & 2,874 & 1,191 & 2,890 & 2,876 & 2,846 & 1,183 \\
\hline R-squared & 0.156 & 0.158 & 0.146 & 0.168 & 0.171 & 0.173 & 0.167 & 0.193 \\
\hline Year fixed effects & Yes & Yes & Yes & Yes & Yes & Yes & Yes & Yes \\
\hline
\end{tabular}




\section{Table A2}

WaVES in VC AND M\&A aCtivities, NOn-US DATA.

Table A2 reports results from logistic regressions of the $\mathrm{VC}$ wave dummies on lagged M\&A and IPO wave dummies on international data only. Industry Capex/TA is lagged industry CAPEX scaled by total assets. Industry Marketto-Book (t-1) is lagged industry market-to-book ratio. Standard errors are clustered by country-industry, year and country fixed effects are included. See Section 4 for details on construction of VC, M\&A, and IPO waves.

\begin{tabular}{|c|c|c|c|c|c|c|c|c|}
\hline & (1) & $(2)$ & $(3)$ & (4) & $(5)$ & (6) & (7) & $(8)$ \\
\hline & $\begin{array}{l}\mathrm{VC} \\
\text { wave }\end{array}$ & $\begin{array}{l}\mathrm{VC} \\
\text { wave }\end{array}$ & $\begin{array}{l}\mathrm{VC} \\
\text { wave }\end{array}$ & $\begin{array}{l}\mathrm{VC} \\
\text { wave }\end{array}$ & $\begin{array}{l}\mathrm{VC} \\
\text { wave }\end{array}$ & $\begin{array}{l}\mathrm{VC} \\
\text { wave }\end{array}$ & $\begin{array}{l}\mathrm{VC} \\
\text { wave }\end{array}$ & $\begin{array}{l}\mathrm{VC} \\
\text { wave }\end{array}$ \\
\hline Lagged M\&A wave & $\begin{array}{l}0.442^{* * *} \\
(0.031)\end{array}$ & $\begin{array}{l}0.164^{* * *} \\
(0.030)\end{array}$ & $\begin{array}{l}0.224^{* * *} \\
(0.050)\end{array}$ & $\begin{array}{l}0.442^{\text {**** }} \\
(0.043)\end{array}$ & $\begin{array}{l}0.159^{* * *} \\
(0.033)\end{array}$ & $\begin{array}{l}0.443^{* * *} \\
(0.044)\end{array}$ & $\begin{array}{l}0.160^{* * *} \\
(0.034)\end{array}$ & $\begin{array}{l}0.240^{* * *} \\
(0.028)\end{array}$ \\
\hline Lagged VC wave & & $\begin{array}{l}0.588^{* * *} \\
(0.024)\end{array}$ & $\begin{array}{l}0.637^{* * *} \\
(0.030)\end{array}$ & & $\begin{array}{l}0.586^{* * *} \\
(0.037)\end{array}$ & & $\begin{array}{l}0.585^{* * *} \\
(0.038)\end{array}$ & $\begin{array}{l}0.639 * * * \\
(0.029)\end{array}$ \\
\hline Lagged IPO wave & & & $\begin{array}{l}0.043 \\
(0.056)\end{array}$ & & & & & $\begin{array}{l}0.048 \\
(0.056)\end{array}$ \\
\hline Industry Capex/TA (t-1) & & & & $\begin{array}{l}0.142 \\
0.142\end{array}$ & $\begin{array}{l}0.257 \\
0.257\end{array}$ & $\begin{array}{l}0.259 \\
0.259\end{array}$ & $\begin{array}{l}0.388 \\
0.388\end{array}$ & $\begin{array}{l}0.415 \\
0.415\end{array}$ \\
\hline Industry Market-to-Book (t-1) & & & & & & $\begin{array}{l}0.000 \\
(0.003)\end{array}$ & $\begin{array}{l}0.001 \\
(0.002)\end{array}$ & $\begin{array}{l}0.004 \\
(0.008)\end{array}$ \\
\hline Observations & 2,672 & 2,672 & 1,148 & 2,444 & 2,444 & 2,413 & 2,413 & 998 \\
\hline Year fixed effects & Yes & Yes & Yes & Yes & Yes & Yes & Yes & Yes \\
\hline Country fixed effects & Yes & Yes & Yes & Yes & Yes & Yes & Yes & Yes \\
\hline
\end{tabular}




\section{Table A3}

INDUSTRY-LEVEL REGRESSIONS OF VC INTENSITY.

Table A3 reports results from industry regressions of VC intensity on lagged M\&A intensity while treating investments by multiple $\mathrm{VC}$ firms in the same portfolio company as multiple deals. \% change in VC deals is the difference between the numbers of $\mathrm{VC}$ deals in the current and previous years divided by the number of deals in the previous year. \% change in $M \& \mathcal{E} A$ deals ( $t-1)$ is lagged percentage growth in the number of M\&A transactions. Industry Capex/TA (t-1) is the lagged industry CAPEX scaled by total assets. Industry Market-to-Book (t-1) is lagged industry market-to-book ratio. \% change in unique $V C$ deals is the percentage growth in the number of unique VC deals. Scaled VC deals (Scaled MESA deals) is the number of VC (M\&A) deals divided by the total number of public firms in the same industry-year in the Worldscope (for international companies) and Compustat (for US companies) databases. Standard errors are clustered by country-industry, year fixed effects are included.

Panel A. Dependent variable - growth in VC deals.

\begin{tabular}{|c|c|c|c|c|}
\hline & $(1)$ & $(2)$ & $(3)$ & $(4)$ \\
\hline & $\begin{array}{l}\% \text { change in } \\
\text { VC deals }\end{array}$ & $\begin{array}{l}\% \text { change in } \\
\text { VC deals }\end{array}$ & $\begin{array}{l}\% \text { change in } \\
\text { VC deals }\end{array}$ & $\begin{array}{l}\% \text { change in } \\
\text { VC deals }\end{array}$ \\
\hline$\%$ change in M\&A deals (t- 1$)$ & $\begin{array}{l}0.072^{* * *} \\
(0.025)\end{array}$ & $\begin{array}{l}0.071^{* * *} \\
(0.027)\end{array}$ & $\begin{array}{l}0.072^{* * *} \\
(0.028)\end{array}$ & $\begin{array}{l}0.124^{* *} \\
(0.055)\end{array}$ \\
\hline Industry Capex/TA (t-1) & & $\begin{array}{l}0.874^{* *} \\
(0.404)\end{array}$ & $\begin{array}{l}1.833 \\
(1.219)\end{array}$ & $\begin{array}{l}1.060 \\
(2.060)\end{array}$ \\
\hline Industry Market-to-Book (t-1) & & & $\begin{array}{l}0.002 \\
(0.001)\end{array}$ & $\begin{array}{l}0.026 \\
(0.023)\end{array}$ \\
\hline$\%$ change in IPOs (t- 1$)$ & & & & $\begin{array}{l}(0.026) \\
(0.022)\end{array}$ \\
\hline Observations & 5,590 & 5,114 & 5,040 & 1,611 \\
\hline R-squared & 0.043 & 0.043 & 0.045 & 0.083 \\
\hline Year fixed effects & Yes & Yes & Yes & Yes \\
\hline
\end{tabular}

Panel B. Dependent variable - number of deals scaled by the number of public firms.

\begin{tabular}{|c|c|c|c|c|c|c|c|c|}
\hline & \multicolumn{2}{|l|}{ (1) } & \multicolumn{2}{|l|}{$(2)$} & \multicolumn{2}{|l|}{$(3)$} & \multicolumn{2}{|l|}{$(4)$} \\
\hline & $\begin{array}{l}\text { Scaled } \\
\text { deals }\end{array}$ & $\mathrm{VC}$ & $\begin{array}{l}\text { Scaled } \\
\text { deals }\end{array}$ & $\mathrm{VC}$ & $\begin{array}{l}\text { Scaled } \\
\text { deals }\end{array}$ & $\mathrm{VC}$ & $\begin{array}{l}\text { Scaled } \\
\text { deals }\end{array}$ & $\mathrm{VC}$ \\
\hline Scaled M\&A deals (t-1) & $\begin{array}{l}0.343^{* * *} \\
(0.085)\end{array}$ & & $\begin{array}{l}0.343^{* * *} \\
(0.087)\end{array}$ & & $\begin{array}{l}0.302^{\text {*** }} \\
(0.087)\end{array}$ & & $\begin{array}{l}0.209^{*} \\
(0.112)\end{array}$ & \\
\hline Industry Capex/TA (t-1) & & & $\begin{array}{l}2.777 \\
(2.907)\end{array}$ & & $\begin{array}{l}1.709 \\
(2.920)\end{array}$ & & $\begin{array}{l}-0.883 \\
(3.876)\end{array}$ & \\
\hline Industry Market-to-Book (t-1) & & & & & $\begin{array}{l}0.286^{* * *} \\
(0.095)\end{array}$ & & $\begin{array}{l}0.542^{\text {*** }} \\
(0.208)\end{array}$ & \\
\hline Scaled IPO deals (t-1) & & & & & & & $\begin{array}{l}0.337 \\
(0.282)\end{array}$ & \\
\hline Observations & 4,897 & & 4,878 & & 4,838 & & 2,172 & \\
\hline R-squared & 0.125 & & 0.127 & & 0.127 & & 0.169 & \\
\hline Year fixed effects & Yes & & Yes & & Yes & & Yes & \\
\hline
\end{tabular}


Table A4

INDUSTRY-LEVEL REGRESSIONS OF VC INTENSITY, EXCLUDING NEW FUNDS

Table A4 reports results from industry regressions of VC intensity on lagged M\&A intensity while excluding new funds (those that first appear in our sample within a 12 month window.) \% change in $V C$ deals is the difference between the numbers of $\mathrm{VC}$ deals in the current and previous years divided by the number of deals in the previous year. \% change in MESA deals ( $t$ - 1 ) is lagged percentage growth in the number of M\&A transactions. Industry Capex/TA (t-1) is the lagged industry CAPEX scaled by total assets. Industry Market-to-Book ( $t$-1) is lagged industry market-to-book ratio. \% change in unique VC deals is the percentage growth in the number of unique VC deals. Scaled VC deals (Scaled MËA deals) is the number of VC (M\&A) deals divided by the total number of public firms in the same industry-year in the Worldscope database. Standard errors are clustered by country-industry, year fixed effects are included.

Panel A. Dependent variable - growth in VC deals.

\begin{tabular}{|c|c|c|c|c|c|c|c|c|}
\hline & (1) & (2) & (3) & (4) & (5) & (6) & (7) & (8) \\
\hline & $\begin{array}{l}\% \\
\text { change } \\
\text { in VC } \\
\text { deals }\end{array}$ & $\begin{array}{l}\% \\
\text { change } \\
\text { in VC } \\
\text { deals }\end{array}$ & $\begin{array}{l}\% \\
\text { change } \\
\text { in VC } \\
\text { deals }\end{array}$ & $\begin{array}{l}\% \\
\text { change } \\
\text { in VC } \\
\text { deals }\end{array}$ & $\begin{array}{l}\% \\
\text { change } \\
\text { in } \\
\text { unique } \\
\text { VC } \\
\text { deals }\end{array}$ & $\begin{array}{l}\% \\
\text { change } \\
\text { in } \\
\text { unique } \\
\text { VC } \\
\text { deals }\end{array}$ & $\begin{array}{l}\% \\
\text { change } \\
\text { in } \\
\text { unique } \\
\text { VC } \\
\text { deals }\end{array}$ & $\begin{array}{l}\% \\
\text { change } \\
\text { in } \\
\text { unique } \\
\text { VC } \\
\text { deals }\end{array}$ \\
\hline$\%$ change in $\mathrm{M} \& \mathrm{~A}$ deals $(\mathrm{t}-1)$ & $\begin{array}{l}0.070^{* * *} \\
(0.024)\end{array}$ & $\begin{array}{l}0.081^{* * *} \\
(0.030)\end{array}$ & $\begin{array}{l}0.083^{* * *} \\
(0.031)\end{array}$ & $\begin{array}{l}0.129^{* *} \\
(0.065)\end{array}$ & $\begin{array}{l}0.103^{* * *} \\
(0.029)\end{array}$ & $\begin{array}{l}0.107^{* * *} \\
(0.033)\end{array}$ & $\begin{array}{l}0.107^{* * *} \\
(0.033)\end{array}$ & $\begin{array}{l}0.093 \\
(0.075)\end{array}$ \\
\hline Industry Capex/TA (t-1) & $(0.024)$ & $\begin{array}{l}(0.030) \\
(0.233)\end{array}$ & $\begin{array}{l}(0.031) \\
(0.779)\end{array}$ & $\begin{array}{l}(0.065) \\
(1.129)\end{array}$ & $(0.029)$ & $\begin{array}{l}(0.033) \\
(0.282)\end{array}$ & $\begin{array}{l}(0.033) \\
(0.282)\end{array}$ & $\begin{array}{l}(0.075) \\
(1.728)\end{array}$ \\
\hline Industry Market-to-Book (t-1) & & & $\begin{array}{l}0.002^{* *} \\
(0.001)\end{array}$ & $\begin{array}{l}0.039^{*} \\
(0.022)\end{array}$ & & & & $\begin{array}{l}0.066^{* *} \\
(0.029)\end{array}$ \\
\hline$\%$ change in IPOs (t-1) & & & & $\begin{array}{l}0.015 \\
(0.025)\end{array}$ & & & & $\begin{array}{l}0.017 \\
(0.035)\end{array}$ \\
\hline Observations & 5,117 & 4,703 & 4,636 & 1,533 & 4,868 & 4,484 & 4,484 & 1,504 \\
\hline R-squared & 0.067 & 0.065 & 0.066 & 0.088 & 0.052 & 0.051 & 0.051 & 0.097 \\
\hline Year fixed effects & Yes & Yes & Yes & Yes & Yes & Yes & Yes & Yes \\
\hline
\end{tabular}

Panel B. Dependent variable - number of deals scaled by the number of public firms.

\begin{tabular}{|c|c|c|c|c|c|c|c|c|}
\hline & $(1)$ & $(2)$ & $(3)$ & $(4)$ & $(5)$ & $(6)$ & $(7)$ & $(8)$ \\
\hline & $\begin{array}{l}\text { Scaled } \\
\text { VC } \\
\text { deals }\end{array}$ & $\begin{array}{l}\text { Scaled } \\
\text { VC } \\
\text { deals }\end{array}$ & $\begin{array}{l}\text { Scaled } \\
\text { VC } \\
\text { deals }\end{array}$ & $\begin{array}{l}\text { Scaled } \\
\text { VC } \\
\text { deals }\end{array}$ & $\begin{array}{l}\text { Scaled } \\
\text { unique } \\
\text { VC } \\
\text { deals }\end{array}$ & $\begin{array}{l}\text { Scaled } \\
\text { unique } \\
\text { VC } \\
\text { deals }\end{array}$ & $\begin{array}{l}\text { Scaled } \\
\text { unique } \\
\text { VC } \\
\text { deals }\end{array}$ & $\begin{array}{l}\text { Scaled } \\
\text { unique } \\
\text { VC } \\
\text { deals }\end{array}$ \\
\hline Scaled M\&A deals (t-1) & $\begin{array}{l}0.196^{* * *} \\
(0.050)\end{array}$ & $\begin{array}{l}0.194^{* * *} \\
(0.050)\end{array}$ & $\begin{array}{l}0.168^{* * *} \\
(0.051)\end{array}$ & $\begin{array}{l}0.116^{*} \\
(0.063)\end{array}$ & $\begin{array}{l}0.227^{* * *} \\
(0.056)\end{array}$ & $\begin{array}{l}0.226^{* * *} \\
(0.056)\end{array}$ & $\begin{array}{l}0.194^{* * *} \\
(0.055)\end{array}$ & $\begin{array}{l}0.142^{* *} \\
(0.069)\end{array}$ \\
\hline Industry Capex/TA (t-1) & & $\begin{array}{l}2.762 \\
(1.967)\end{array}$ & $\begin{array}{l}2.115 \\
(1.914)\end{array}$ & $\begin{array}{l}0.216 \\
(2.406)\end{array}$ & & $\begin{array}{l}1.916 \\
(1.877)\end{array}$ & $\begin{array}{l}1.481 \\
(1.858)\end{array}$ & $\begin{array}{l}0.321 \\
(2.526)\end{array}$ \\
\hline Industry Market-to-Book (t-1) & & & $\begin{array}{l}0.175^{* * *} \\
(0.067)\end{array}$ & $\begin{array}{c}0.323^{* *} \\
(0.139)\end{array}$ & & & $\begin{array}{l}0.238^{* * *} \\
(0.076)\end{array}$ & $\begin{array}{l}0.445^{* * *} \\
(0.155)\end{array}$ \\
\hline Scaled IPO deals $(\mathrm{t}-1)$ & & & & $\begin{array}{l}0.206 \\
(0.180)\end{array}$ & & & & $\begin{array}{l}0.189 \\
(0.166)\end{array}$ \\
\hline Observations & 4,495 & 4,479 & 4,442 & 2,036 & 4,416 & 4,401 & 4,367 & 2,016 \\
\hline R-squared & 0.122 & 0.125 & 0.122 & 0.175 & 0.132 & 0.133 & 0.138 & 0.189 \\
\hline Year fixed effects & Yes & Yes & Yes & Yes & Yes & Yes & Yes & Yes \\
\hline
\end{tabular}


Table A5

INSTRUMENTING CROSS-BORDER M\&A WITH CHANGES IN LOCAL TREASURY RATES

Table A5 reports results from two-stage IV regressions. In the first stage we instrument cross-border M\&A deals (scaled by the number of public firms) by the change in the local treasury rates. In the second stage with predict domestic VC deals with lagged instrumented CB M\&A deals. Year fixed effects are included, standard errors are clustered by country.

\begin{tabular}{llll}
\hline & \multicolumn{1}{c}{$(1)$} & \multicolumn{1}{c}{$(2)$} \\
& $\begin{array}{l}\text { Scaled CB } \\
\text { M\&A deals }\end{array}$ & $\begin{array}{l}\text { Scaled } \\
\text { deals }\end{array}$ & $\begin{array}{l}\text { Scaled } \\
\text { unique VC } \\
\text { deals }\end{array}$ \\
\hline Change in risk-free rate & $-0.377^{* *}$ & & \\
Median market-to-book & $(0.164)$ & & \\
Median Investment & $0.019^{* * *}$ & $0.788^{* *}$ & $0.670^{* *}$ \\
GDP growth & $(0.003)$ & $(0.335)$ & $(0.304)$ \\
Instrumented CB M\&A, lagged & 6.587 & $-24.665^{*}$ & $-21.846^{*}$ \\
& $(41.893)$ & $(12.541)$ & $(10.848)$ \\
Observations & $0.590^{* *}$ & $0.200^{* *}$ & $0.178^{* *}$ \\
R-squared & & $(0.079)$ & $(0.064)$ \\
Year fixed effects & 613 & $0.212^{* *}$ & $0.171^{* *}$ \\
\hline
\end{tabular}


Table A6

INDUSTRY-LEVEL REGRESSIONS OF VC INTENSITY, INCLUDING HORIZONTAL MERGERS ONLY

Table A6 reports results from industry regressions of VC intensity on lagged M\&A intensity while including horizontal mergers only. \% change in $V C$ deals is the difference between the numbers of $\mathrm{VC}$ deals in the current and previous years divided by the number of deals in the previous year. \% change in $M E \mathcal{E} A$ deals ( $t-1)$ is lagged percentage growth in the number of M\&A transactions. Industry Capex/TA ( $t$-1) is the lagged industry CAPEX scaled by total assets. Industry Market-to-Book (t-1) is lagged industry market-to-book ratio. \% change in unique $V C$ deals is the percentage growth in the number of unique $\mathrm{VC}$ deals. Scaled VC deals (Scaled MEA deals) is the number of VC (M\&A) deals divided by the total number of public firms in the same industry-year in the Worldscope database. Standard errors are clustered by country-industry, year fixed effects are included.

Panel A. Dependent variable - growth in VC deals.

\begin{tabular}{|c|c|c|c|c|c|c|c|c|}
\hline & (1) & (2) & (3) & (4) & (5) & (6) & (7) & (8) \\
\hline & $\begin{array}{l}\% \\
\text { change } \\
\text { in VC } \\
\text { deals }\end{array}$ & $\begin{array}{l}\% \\
\text { change } \\
\text { in VC } \\
\text { deals }\end{array}$ & $\begin{array}{l}\% \\
\text { change } \\
\text { in VC } \\
\text { deals }\end{array}$ & $\begin{array}{l}\% \\
\text { change } \\
\text { in VC } \\
\text { deals }\end{array}$ & $\begin{array}{l}\% \\
\text { change } \\
\text { in } \\
\text { unique } \\
\text { VC } \\
\text { deals }\end{array}$ & $\begin{array}{l}\% \\
\text { change } \\
\text { in } \\
\text { unique } \\
\text { VC } \\
\text { deals }\end{array}$ & $\begin{array}{l}\% \\
\text { change } \\
\text { in } \\
\text { unique } \\
\text { VC } \\
\text { deals }\end{array}$ & $\begin{array}{l}\% \\
\text { change } \\
\text { in } \\
\text { unique } \\
\text { VC } \\
\text { deals }\end{array}$ \\
\hline$\%$ change in M\&A deals $(\mathrm{t}-1)$ & $\begin{array}{l}0.041^{* *} \\
(0.017)\end{array}$ & $\begin{array}{l}0.040^{* *} \\
(0.019)\end{array}$ & $\begin{array}{l}0.039^{* *} \\
(0.019)\end{array}$ & $\begin{array}{l}0.086^{* *} \\
(0.037)\end{array}$ & $\begin{array}{l}0.062^{* *} \\
(0.025)\end{array}$ & $\begin{array}{c}0.047^{* *} \\
(0.023)\end{array}$ & $\begin{array}{l}0.047^{* *} \\
(0.023)\end{array}$ & $\begin{array}{l}0.062 \\
(0.041)\end{array}$ \\
\hline Industry Capex/TA (t-1) & & $\begin{array}{l}0.148 \\
(0.172)\end{array}$ & $\begin{array}{l}0.434 \\
(0.635)\end{array}$ & $\begin{array}{l}-0.443 \\
(0.539)\end{array}$ & & $\begin{array}{l}0.436^{* *} \\
(0.217)\end{array}$ & $\begin{array}{l}0.436^{* *} \\
(0.217)\end{array}$ & $\begin{array}{l}-0.782 \\
(0.723)\end{array}$ \\
\hline Industry Market-to-Book (t-1) & & & $\begin{array}{l}0.002^{* *} \\
(0.001)\end{array}$ & $\begin{array}{l}0.036^{*} \\
(0.020)\end{array}$ & & & & $\begin{array}{l}0.063^{* * *} \\
(0.024)\end{array}$ \\
\hline$\%$ change in IPOs (t-1) & & & & $\begin{array}{l}0.003 \\
(0.018)\end{array}$ & & & & $\begin{array}{l}-0.000 \\
(0.026)\end{array}$ \\
\hline Observations & 4,469 & 4,247 & 4,207 & 1,516 & 4,275 & 4,066 & 4,066 & 1,495 \\
\hline R-squared & 0.069 & 0.067 & 0.068 & 0.101 & 0.056 & 0.055 & 0.055 & 0.115 \\
\hline Year fixed effects & Yes & Yes & Yes & Yes & Yes & Yes & Yes & Yes \\
\hline
\end{tabular}

Panel B. Dependent variable - number of deals scaled by the number of public firms

\begin{tabular}{|c|c|c|c|c|c|c|c|c|}
\hline & (1) & $(2)$ & (3) & (4) & (5) & (6) & (7) & (8) \\
\hline & $\begin{array}{l}\text { Scaled } \\
\text { VC } \\
\text { deals }\end{array}$ & $\begin{array}{l}\text { Scaled } \\
\text { VC } \\
\text { deals }\end{array}$ & $\begin{array}{l}\text { Scaled } \\
\text { VC } \\
\text { deals }\end{array}$ & $\begin{array}{l}\text { Scaled } \\
\text { VC } \\
\text { deals }\end{array}$ & $\begin{array}{l}\text { Scaled } \\
\text { unique } \\
\text { VC } \\
\text { deals }\end{array}$ & $\begin{array}{l}\text { Scaled } \\
\text { unique } \\
\text { VC } \\
\text { deals }\end{array}$ & $\begin{array}{l}\text { Scaled } \\
\text { unique } \\
\text { VC } \\
\text { deals }\end{array}$ & $\begin{array}{l}\text { Scaled } \\
\text { unique } \\
\text { VC } \\
\text { deals }\end{array}$ \\
\hline Scaled M\&A deals (t-1) & $\begin{array}{l}0.345^{* * *} \\
(0.102)\end{array}$ & $\begin{array}{l}0.343^{* * *} \\
(0.103)\end{array}$ & $\begin{array}{l}0.310^{* * *} \\
(0.104)\end{array}$ & $\begin{array}{l}0.279^{* *} \\
(0.133)\end{array}$ & $\begin{array}{l}0.437^{* * *} \\
(0.127)\end{array}$ & $\begin{array}{l}0.436^{* * *} \\
(0.128)\end{array}$ & $\begin{array}{l}0.387^{* * *} \\
(0.124)\end{array}$ & $\begin{array}{l}0.379^{* *} \\
(0.161)\end{array}$ \\
\hline Industry Capex/TA (t-1) & & $\begin{array}{l}3.268 \\
(2.182)\end{array}$ & $\begin{array}{l}2.153 \\
(2.112)\end{array}$ & $\begin{array}{l}0.229 \\
(2.711)\end{array}$ & & $\begin{array}{l}2.936 \\
(2.344)\end{array}$ & $\begin{array}{l}1.825 \\
(2.280)\end{array}$ & $\begin{array}{l}-0.013 \\
(3.019)\end{array}$ \\
\hline Industry Market-to-Book (t-1) & & & $\begin{array}{l}0.167^{* *} \\
(0.071)\end{array}$ & $\begin{array}{l}0.212^{*} \\
(0.116)\end{array}$ & & & $\begin{array}{l}0.255^{* * *} \\
(0.091)\end{array}$ & $\begin{array}{l}0.352^{* *} \\
(0.143)\end{array}$ \\
\hline Scaled IPO deals $(\mathrm{t}-1)$ & & & & $\begin{array}{l}0.255 \\
(0.224)\end{array}$ & & & & $\begin{array}{l}0.242 \\
(0.216)\end{array}$ \\
\hline Observations & 4,128 & 4,118 & 4,099 & 2,003 & 4,067 & 4,058 & 4,039 & 1,985 \\
\hline R-squared & 0.111 & 0.115 & 0.118 & 0.177 & 0.122 & 0.127 & 0.138 & 0.199 \\
\hline Year fixed effects & Yes & Yes & Yes & Yes & Yes & Yes & Yes & Yes \\
\hline
\end{tabular}




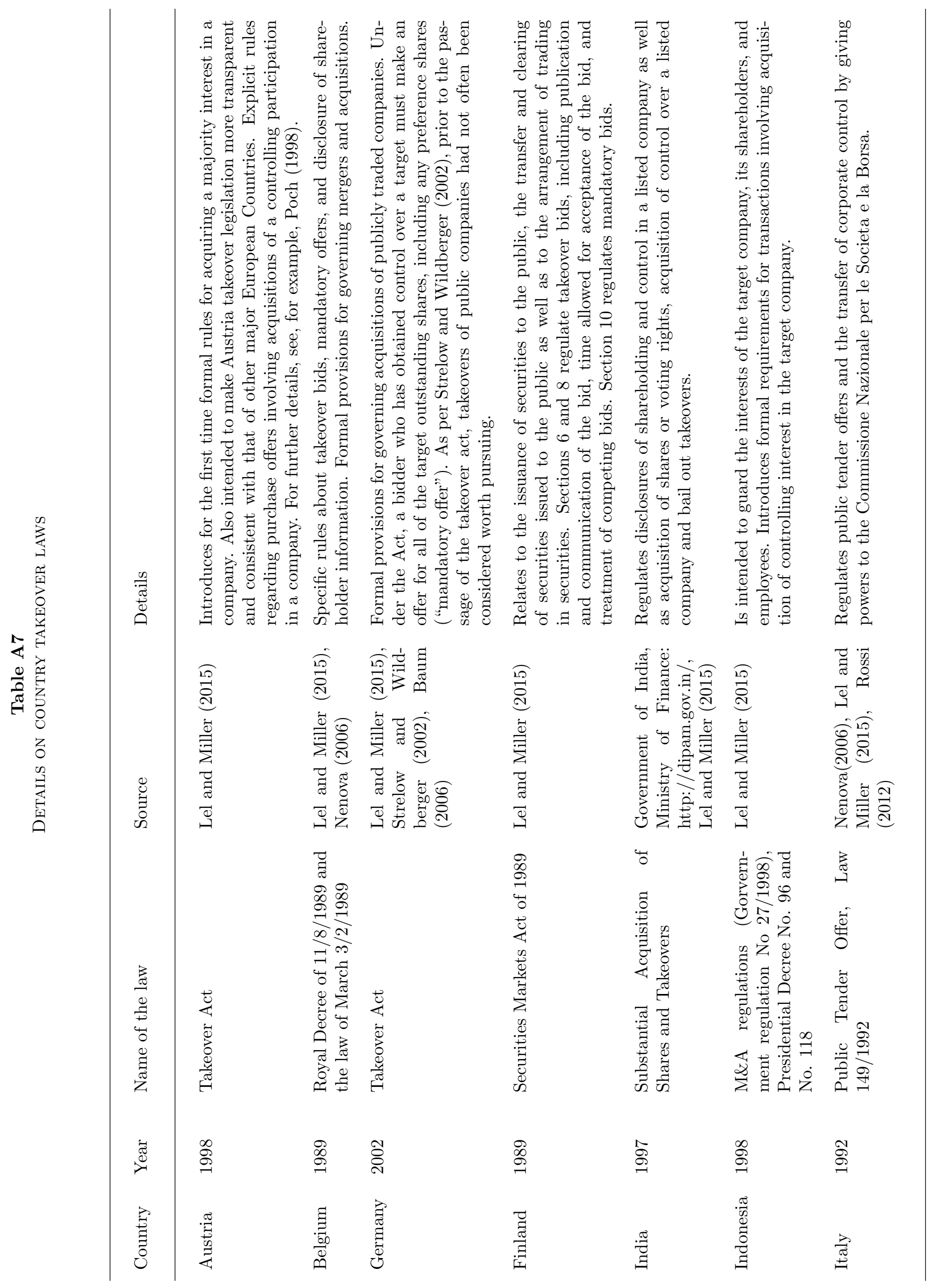




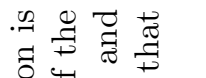

용

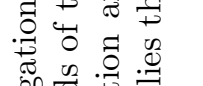

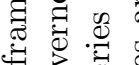

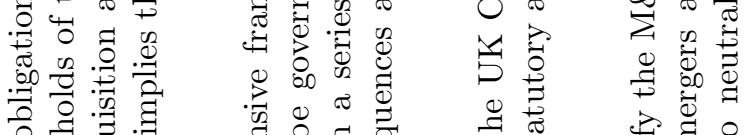

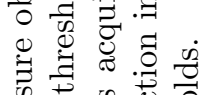

की

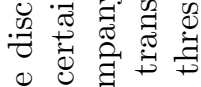

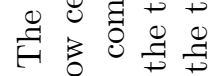

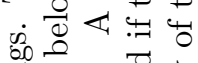

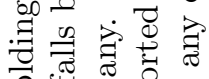

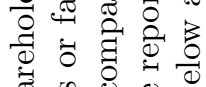

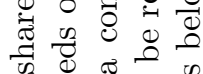

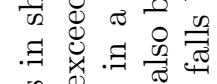

की

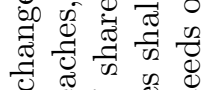

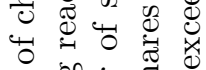

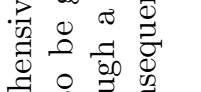

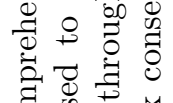

घ्वे

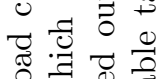

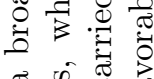

ช

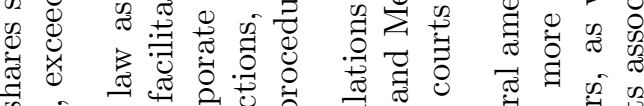

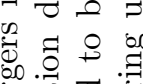

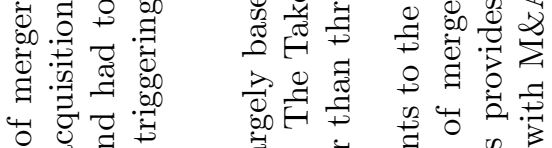

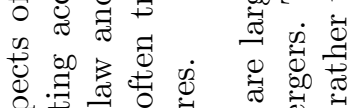

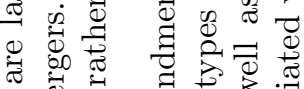

क

के 흥 है है

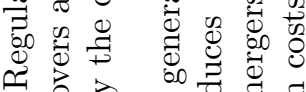

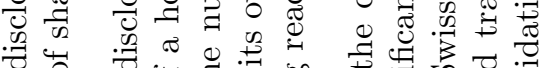

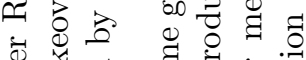

密覀要

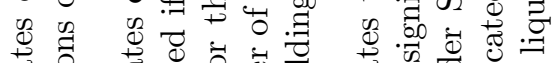

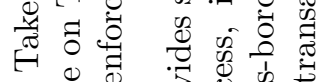

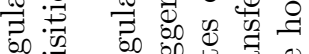

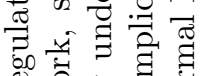

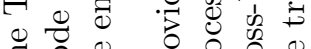

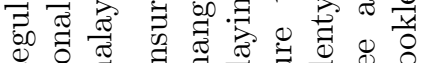

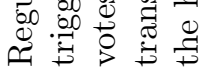

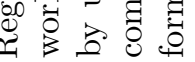

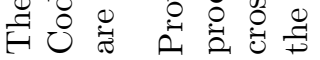

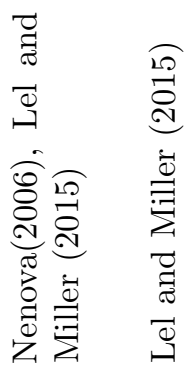

苞

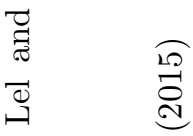

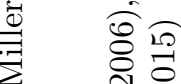

च

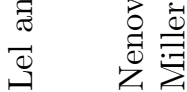

量

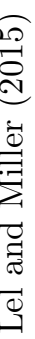

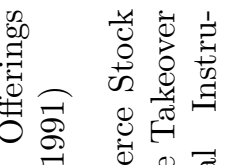

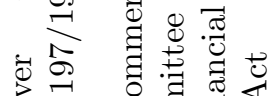

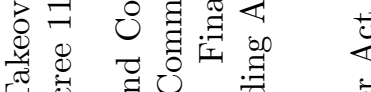

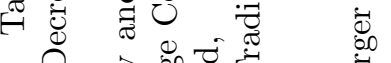

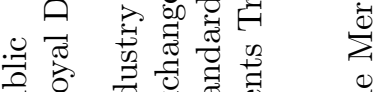

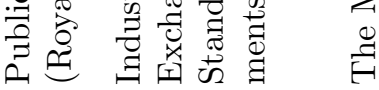

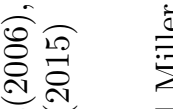

范

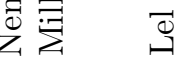

进

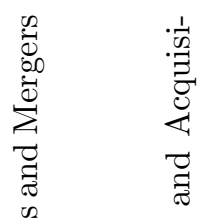

若 邑

局

ङ્ڤ

ت્.

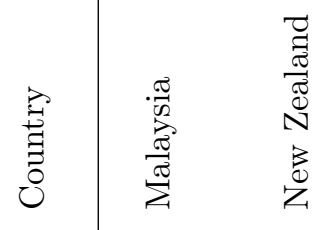

昡量
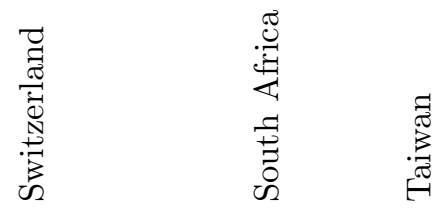